\title{
The Dynamics of Entrepreneurial Networks in a Transition Economy: The Case of Russia
}

\author{
By: Bat Batjargal
}

Working Paper Number 350

December 2000 


\title{
THE DYNAMICS OF ENTREPRENEURIAL NETWORKS IN A TRANSITION ECONOMY: THE CASE OF RUSSIA
}

\author{
BAT BATJARGAL ${ }^{*}$ \\ Davis Center for Russian Studies \\ Harvard University \\ 1737 Cambridge Street \\ Cambridge, MA 02138
Guanghua School of Management
Peking University
Beijing, 100871
People's Republic of China \\ Tel: 86-10-6275 7763 \\ Email: bbat@gsm.pku.edu.cn
}

\footnotetext{
* I am grateful to the International Research \& Exchange Board (IREX) for its financial support for this research. IREX is not responsible for the views expressed herein. I would like to thank seminar participants at the Davis Center for Russian Studies at Harvard University, Center for International Development at Harvard University and London Business School for constructive comments on earlier versions of the paper.
} 


\title{
THE DYNAMICS OF ENTREPRENEURIAL NETWORKS IN A TRANSITION ECONOMY: THE CASE OF RUSSIA
}

\begin{abstract}
The dynamics of personal networks of entrepreneurs in Russia are explored in this paper. Drawing on the social embeddedness perspective and social network theory, I examine the impacts of initial network range, previous occupational status of entrepreneurs and firm performance on the changes in structural, relational and resource dimensions of entrepreneurial social capital over time. The face-to-face interviews with 75 Russian entrepreneurs in 1995 and the follow-up study in 1999 comprise the empirical data of the paper. The dynamics of social capital are determined by the initial network range and firm performance: the better the initial network and firm performance the less the likelihood of increase in various elements of entrepreneurs' social capital.
\end{abstract}

KEY WORDS: dynamics, entrepreneurial networks, Russia

\section{BACKGROUND}

In his seminal essay, Granovetter (1985) postulated that actions of economic agents are embedded in concrete, ongoing systems of social relations and these relations facilitate and constrain agents' profit and rent seeking actions. Social capital defined as networks of relationships and assets located in these networks (Bourdieu, 1986, Burt, 1997a, Coleman, 1988) has been found positively influencing firm performance (Baker, 1990), product innovation (Tsai \& Ghoshal, 1998), and industry-wide network formation (Walker, Kogut \& Shan, 1997). Similarly, social capital of individuals facilitates job and status attainment (Lin, Ensel, \& Vaughn, 1981, Marsden \& Hurlbert, 1988), enhances individual's power (Krackhardt, 1990) and career mobility (Podolny \& Baron, 1997), and impacts CEO compensation (Belliveau, O’Reilly III, \& Wade, 1996). Research on personal networks of entrepreneurs revealed that entrepreneurs perceive and exploit business opportunities in disconnected networks (Burt, 1992), obtain information, advice and social support from network alters (Aldrich \& Zimmer, 1986, Birley, 1985, Nohria, 
1992), control and manage exchange structures through network dyads (Larson, 1992), access financial capital (Shane \& Cable, 1999), and get an endorsement from prestigious players to influence perceptions of the quality of their ventures (Stuart, Hoang, \& Hybels, 1999).

On the other hand, there is growing empirical evidence that the social embeddedness has a negative aspect: tightly controlled relationships reinforce obligations and expectations that may limit freedom of economic agents to recognize and exploit new opportunities (Light \& Isralowitz, 1997, Podolny \& Page, 1998). Previously instrumental relationships may turn into "dark resources" that constrain rent seeking activities of entrepreneurs affecting negatively their sales and other performance indicators (Bean \& Bell-Rose, 1999, Portes, 1995). The bulk of the empirical research on social capital, thus, has been devoted to the aspect of instrumental utilisation of personal networks (Portes, 1998) and increasingly the "dark side" of social relations for entrepreneurship.

While understanding how social capital of economic agents does influence the outcome of their actions is vital, the explaining and decoding of how personal networks of entrepreneurs develop and evolve over time is crucial for entrepreneurial sustainability. Despite its practical and academic importance, the theme has attracted a very little attention of management researchers (Johannisson, 1996, Steier, 2000). In this paper, I examine the dynamics of entrepreneurs' personal networks over time and assess the impacts of such indicators as initial network range, firm performance and social status of entrepreneurs on the development and evolution of social networks of entrepreneurs. The context of the study is a large transition economy - the Russian Federation. Since Russia is going through unparalleled social and economic changes, the country's context 
is an appropriate research site for testing of research hypotheses on network dynamics of entrepreneurs. In the present study, I argue that entrepreneurial performance and original network range of entrepreneurs have significant impacts on the changes in structural, relational and resource parameters of networks whereas social origin does not affect network dynamics.

I seek to make two contributions to the research literature: First, by applying the embeddedness argument and social capital theory developed and tested in the Western social environment to the Russian reality, I expand the paradigm boundary to formerly communist societies. Second, I examine the dynamics of personal networks of entrepreneurs over time and explain the factors that determine structural, relational and resource changes of entrepreneurs' personal networks - an important but neglected area in network research and entrepreneurial studies.

Resources of individuals defined as valuable assets possessed by persons and embedded in social networks constitute the fundamental linkage between actors' purposive actions and their outcomes, e.g., entrepreneurial entry and exit (Abell, 1996). The pattern of dispersion of various resources among individuals at a given moment in time is a function of social structure (Stinchcombe, 1965). Different resources including knowledge and social resources are dispersed unevenly across the hierarchical as well as segmented groups in society (Anheier, Gerhards \& Romo, 1995, Hayek, 1945). The volume of resources possessed by an individual or groups is contingent on the overall position of that individual or group in the social space. This uneven resource dispersion across social groups and individuals is referred to the resource heterogeneity of social actors. Economic agents including entrepreneurs are heterogeneous in terms of network 
range (Burt, 1983b), relations and contact resources (Lai, Lin \& Leung, 1998). The resource heterogeneity forms the set of constraints that governs the functioning of society in a durable way determining the chances of success for instrumental actions of individuals (Bourdieu, 1986).

Social embeddedness is a dynamic continuous process as much as stable exchange relations. Social capital of entrepreneurs, therefore, evolves and develops over time as a function of venture life-cycle (Steier, 2000), industry and geographic region (Johannisson, 1996).

At the start-up stage of new venturing entrepreneurs are likely to seek out actively investors and business angels for capital, and their networking strategy will focus more on capital providers such as business angels (Steier, 2000). With new venture growth structural composition, relational content and resource volumes of networks will change: networks are likely to contain more clients and suppliers rather than initial investors; new investors are likely to be those with greater financial resources than initial investors; business relationships become more and more formal and institutionalised in contrast to initial informal relations based on individual acquaintances. Networks of failing entrepreneurs are likely to disintegrate, and the process may force them to adapt a different networking strategy.

Structural and other parameters of industries may produce particular networking patterns of entrepreneurs: retail trade firms are likely to have numerous and disconnected clients that make them less dependent on a certain client in contrast to manufacturing firms that usually have a few key clients upon whom their revenue depends. Urban entrepreneurs are likely to have more dynamic networks due to large pools of potential 
contacts whereas rural entrepreneurs may have less dynamic but stable networks due to the limited population of potential alters.

The dynamics of social capital are path-dependent (Granovetter, 1990, Stark, 1996). Those with higher initial social position are likely to have more high status and resource rich players in their network, and these network clusters may function as closed societies such as the Oxbridge network - "the old boys network" in England.

Arguably, venture development and entrepreneur development is a coevolutionary process where entrepreneur influences firm performance as much as firm performance affects attributes of entrepreneurs such as experience, tacit knowledge or resource acquisition skills. While relatively successful entrepreneurs may adapt conservative or persistent networking behaviour (Aldrich, 1982), those that under perform may pursue more expansionist networking as a learning effect from successful peers. In this perspective, entrepreneurial performance may have a major effect on the dynamics of entrepreneurial social capital.

Sociologists elaborated three dimensions of individual's social capital: structural embeddedness - the structure of the overall network of relations, relational embeddedness - the extent to which economic actions are affected by the quality of actors' personal relations (Granovetter, 1990: 98), and cognitive embeddedness - the degree to which an individual shares common code and systems of meaning with a community or collective (Nahapiet \& Ghoshal, 1998: 244). Fourth dimension of social capital may be articulated as resource embeddedness - the degree to which network ties contain valuable instrumental resources (Lai et al, 1998, Lin \& Dumin, 1986, Marsden \& Hurlbert, 1988). The resource embeddedness has been referred to "the material quality of ties" (Uzzi, 
1996: 675), and it is a function of attributes and characteristics of individual alters, e.g., high status contact versus low status contact (Ibarra, 1993). In this study, I focus upon structural embeddedness, relational embeddedness and resource embeddedness of entrepreneurs' social capital.

I operationalize structural embeddedness as network range that include network size, heterophily (Burt, 1983b) and homophily. Network size is defined as the number of direct ties involving individual units (Burt, 1983b, Marsden, 1990, Moore, 1990). Network heterophily refers to the degree which an ego network contains diverse alters, e.g., demographic characteristics or occupational status (Burt, 1983b, Ibarra, 1993, Marsden, 1987, Renzulli, Aldrich \& Moody, 1999). Network homophily is conceptualized as the extent to which pairs of alters in a network are similar in various attributes including occupational (Ibarra, 1992, 1993).

Relational embeddedness has been interpreted as relational content (Burt, 1983a, 1997b, Podolny \& Baron, 1997), tie strength (Marsden \& Campbell, 1984), and relational trust (Galunic \& Moran, 1999, Tsai \& Ghoshal, 1998). I operationalize relational embeddedness as "the friendship domain" indicating strong ties and "the acquaintance domain" indicating weak ties (Burt, 1983a, Krackhardt, 1992, Lin \& Dumin, 1986).

Lai et al operationalized resource embeddedness as contact's resource characteristics that are contingent upon occupational status, authority position, and core versus peripheral sector (Lai et al, 1998). I operationalize resource embeddedness as the extent to which an egocentric network is comprised of actors of high socioeconomic status and the extent to which entrepreneurs have been able to marshal financial and material resources from their personal networks. 


\section{THE RUSSIAN CONTEXT}

The instrumental use of personal connections characterized Soviet society at its core. Blat - the system of informal contacts has served as an alternative social mechanism for overcoming rigidities in Soviet factory's production and supply practices (Berliner, 1957) and obtaining consumer goods and services under the rationing system that characterized the Soviet economy (Ledeneva, 1998). The scale of informal ties and resources located in these networks were dependent on the political power of social actors (Shkaratan \& Figatner, 1992). The transition to market economy, however, has changed fundamentally the way Russians build personal networks and utilize them for business and personal goals (Kosova, 1999, Ledeneva, 1998). Radaev, a leading Russian sociologist, said in an interview: "During the Soviet period Russians built and used personal networks partly to survive and partly to help each other (vyruchit'). But now the way people network in this country is becoming more and more quid pro quid. The material reciprocity and rational calculations about contacts' resources are the main selection factor for network recruitment. In other words, people are becoming more and more systematic in their networking strategy and pay much attention to recruit resource rich and powerful contacts in their personal networks" (Author's interview, May 1999, Moscow). This indicates that personal networks of Russian entrepreneurs are more turbulent and dynamic in comparison to entrepreneurial networks in relatively stable market economies such as the West.

Based upon the logic of social embeddedness and assumptions on the network dynamics, I propose a number of empirical hypotheses. 


\section{HYPOTHESES}

\section{Network Dynamics}

Original Network Range. The dynamics of personal networks of entrepreneurs are a function of the original state of networks (Burt, 1992, Johannisson, 1996, Steier, 2000, Uzzi, 1997). As network clusters evolve, friends of friends begin to be included and that expands cluster boundaries to contacts in other clusters pushing the size of ego networks further. Third-party referrals and past relationships bring in new ties to the cluster and this shapes the original network range, relations and resource configurations. As a venture develops, entrepreneurs focus on the quality of the network composition such as nonredundancy or heterophily changing their network morphology (Steier, 2000).

H1a. The greater the original network range the greater the increase in structural elements of entrepreneurs' networks.

H1b. The greater the original network range, the greater the increase in relational elements of entrepreneurs' networks.

H1c. The greater the original network range the greater the increase in resources of entrepreneur's networks.

Original Occupational Status. It is assumed that original social position of entrepreneurs, i.e., family background or status of first job, may be associated with patterns of change in networks: higher structural location within the social hierarchy enables them to screen better potential ties and recruit more diverse and resource-rich contacts (Lin, 1990). Prestigious location itself makes more attractive to other people, easing the network expanding effort (Burt, 1992: 23). In this perspective, the status of the original position may predict network development of entrepreneurs.

H2a. The higher the original social status the greater the increase in structural elements of entrepreneurs' networks. 
$H 2 b$. The higher the original social status the greater the increase in relational elements of entrepreneurs' networks.

H2c. The higher the original social status the greater the increase in resourcefulness of entrepreneur's networks.

Firm Performance and Structural Dynamics of Networks. I predict the converse relationship between firm performance and changes in structural features of networks. Successful entrepreneurs are likely to be persistent in their networking since their networks are already sizeable and heterophilous providing profitable economic exchanges (Aldrich, 1982). Opportunistic entrepreneurs are likely to manage better the tension between network growth and effectiveness since efficiency may decline with the increase in size (Burt, 1992: 24). Less successful entrepreneurs may deliberately search out new alters to expand their opportunity horizons.

H3a. The better the firm performance the less the increase in network size of entrepreneurs.

H3b. The better the firm performance the less the increase in network heterophily of entrepreneurs.

H3c. The better the firm performance the less the increase in network homophily of entrepreneurs.

Firm Performance and Relational Dynamics of Networks. Changes in strong and weak ties are affected inversely by entrepreneurial performance. Making most out of spotted opportunities in networks will pressurize friendship ties resulting in either friends fleeing or excluding friends from business dealings. Past fruitful relationships precondition turning of previously weak ties into strong ties, and those weak ties that are instrumentally useless are likely to be dumped. Entrepreneurs who are lagging behind will try to develop strong ties with key clients and suppliers and intentionally keep many 
new and old relationships weak to preserve the structural autonomy for opportunistic behaviour. Ethnographic studies in Russia confirm that entrepreneurs exclude their friends from deals and keep a distance with acquaintances (Ledeneva, 1998: 196, 200).

H4a. The better the firm performance the less the increase in strong ties of entrepreneurs.

$H 4 b$. The better the firm performance the less the increase in weak ties of entrepreneurs.

Firm Performance and Resource Dynamics of Networks. Wealthy, powerful and prestigious actors are few and likely to reside centrally in clusters of successful entrepreneurs. These clusters are likely to have clear boundaries to protect relationships from opportunistic poachers from less resourceful clusters. Failing entrepreneurs, therefore, will have a moderate success in poaching of resourceful contacts. The perception of under performance also makes them unattractive to resource-rich alters such as venture capitalists and bankers perpetuating the vicious circle of being at the bottom. Well-do firms are likely to use formal and informal channels for additional finance since they are financially solvent in contrast to failing firms that are likely to seek more and cheaper financial resources from informal sources.

H5a. The better the firm performance the less the increase in network resourcefulness of entrepreneurs.

$H 5 b$. The better the firm performance the less the increase in mobilized resources of entrepreneurs.

\section{METHODOLOGY}

\section{Sample and Data Collection}

The empirical data of the study is composed of the face-to-face interviews with 75 Russian entrepreneurs in February-June 1995, and the follow-up interviews with 56 
original respondents in March-May 1999. Pilot interviews with six Moscow firms were conducted in August 1994.

In three Russian cities, viz., Moscow, Ekaterinburg and Pterozavodsk, I selected firms on the basis of a stratified random sampling procedure. The computerised database of registered businesses of the Moscow City Committee of Statistics, Business Assistance Centre of the Sverdlovsk Regional Administration in Ekaterinburg, and the State Committee of Statistics of the Republic of Karelia in Petrozavodsk were used as sampling populations. I created twelve lists of firms (four industries and three sizes) each of which contained twenty firm names.

Banks were classified in accordance with the following criteria: small charter funds < US\$50 000, medium charter funds US\$50 001-250 000, and large charter funds > US\$250 001. This grouping was confirmed in interviews with Russian experts and Central bank officials. A similar classification has been established in another study of Russian banks (Lapidus \& van de Waal-Palms, 1997). In manufacturing and the resource sector, firms were grouped: small $-<100$ employees, medium - 101-500 employees, and large - > 501 employees. Trade firms were classified: small - < 50 employees, medium 51-200 employees, and large - > 201 employees. The classification is based on the definition of small firms in the Russian law and discussions with Russian experts (Rossiiskaya federatsiya, 1995).

Every second firm on these lists was selected for contact. In 1995, 120 entrepreneurs were contacted and 82 agreed to be interviewed. The response rate was 68 percent. 7 respondents were discovered as ineligible in the field, so that the final sample consisted of 75 entrepreneurs and directors. There were 50 new ventures and 25 
privatized companies. Interviews were conducted with a specially designed questionnaire that contained questions on entrepreneurial networks and firm characteristics. The follow-up study in 1999 concentrated on network dynamics and firm performance. I reinterviewed 56 original respondents.

Insert Table 1 and 2 about here

Financial data was collected from firms as well as other sources such as the Central Bank of Russia, Association of Russian Banks, the Foundation for Small Business Development in three cities, and local tax offices. About a half of the sample firms provided annual reports that contained accounting information. In most occasions, financial directors or chief accountants were interviewed additionally on financial issues. Accounting data in Roubles have been deflated by the year's average exchange rate of US\$ and Russian Roubles published in The Economist. The reliability and consistency of company financial statements still remains questionable in Russia although significant progress has been made for the last few years to bring Russian accounting practices in the line with the Western standard.

\section{Independent Variables}

There are three independent variables in this paper that are assumed to influence the dynamics of personal networks of entrepreneurs: Original network range, original occupational status and firm performance.

Original network range. Network size is measured by the number of ties indicated by entrepreneurs. I presented a table where twelve types of occupations (high rank official in ministries and agencies, middle and low rank official in ministries and agencies, high rank official in local governments, middle and low rank official in local 
governments, managers of large banks, managers of medium and small banks, managers of large manufacturing plants, managers of medium and small manufacturing plants, managers of large trade firms, managers of medium and small trade firms, managers large resource sector firms, and managers of medium and small resource sector firms) were listed in rows, and two types of tie strength (friendship and acquaintances) were placed in columns (Lin \& Dumin, 1986). I asked the respondents to indicate how many people were in each cell. This table was used in 1995 interviews and the follow-up interviews in 1999 to capture the egocentric network size and its dynamics.

Network heterophily measures the degree to which an egocentric network contains alters from different sectors, i.e., positions in ministries and local governments, banking, trade, manufacturing, and the resource sector. It is measured as the proportion of contacts from other industries.

Network homophily is measured as the percentage of contacts from the same industry.

Original occupational status. Status of first job is scaled as low status denoted "one", middle status denoted "two", and high status denoted "three". Those who started as workers and peasants were categorized as low status, and those who started in intelligentsia were regarded as middle status, and those who started in party and state bureaucracy were categorized as high status.

Firm performance. Organisational performance may be measured in various ways (March \& Sutton, 1997, Meyer, 1994). In this paper, firm performance is measured by sales growth, operating profit margin, and return on assets (Earle et al, 1996). Sales growth for each year (1996, 1997 and 1998) and the average sales growth for three years 
were expressed in percentage. I use sales growth rather than sales figures because of the mixed sample of large, medium and small firms as well as firms from four different industries. Operating profit margin (PM) for each year, the average operating profit, return on assets (ROA) for each year and the average return on assets were expressed in percentage.

\section{Dependent Variable}

The dependent variable is network dynamics and it is measured by change in network size, change in network heterophily, change in network homophily, change in strong ties, change in weak ties, change in network resourcefulness, and resources mobilized in 1999.

Change in network size is measured by the difference between network size-95 and network size-99. Change in network heterophily captures the difference between network heterophily-95 and network heterophily-99. Change in network homophily scales the difference between network homophily-95 and network homophily-99.

Change in strong ties is measured by the difference between strong ties-95 and strong ties-99. Strong ties are the number of friends. Change in weak ties is measured by the difference between weak ties-95 and weak ties-99. Weak ties capture the number of acquaintances. I presented the Russian translations "drug" as friend and "znakomyi" as acquaintance due to the culture sensitive nature of these concepts. It is reasonable to assume that respondents have clearly distinguished their drug from znakomyi because of the Russian communal traditions as well as informal exchange practices (Ledeneva, 1998). 
Change in resourcefulness is measured by the difference between resourcefulness-95 and resourcefulness-99. Network resourcefulness captures the number of high rank officials in ministries, high rank officials in local governments, managers of large banks, managers of large manufacturing plants, managers of large trade firms, and managers of large resource sector firms.

Financial resources mobilized 95 and financial resources mobilized 99 are binary variables of one if resources were mobilized before and after 1995 interviews and zero if resources were not mobilized.

\section{Control Variables}

Industry (banking, trade, manufacturing, and the resource sector), firm size (large, medium and small), region (Moscow, Ekaterinburg, and Petrozavodsk) and firm origin (new venture versus privatized) are controlled in this study. Three cities represent Russia's regional economic diversity well. Moscow is the financial and commercial center whereas Ekaterinburg is famous for its heavy industry. In Petrozavodsk, the capital city of the Republic of Karelia, the timber industry and trade is highly developed. All control variables were turned into dummies and included in the regression analyses.

\section{RESULTS}

\section{Descriptive Statistics}

The performance indicators in Table 3 show that Russian firms performed poorly: the average sales growth for three years was $1 \%($ s.d. $=0.33)$, average profit margin was $-22 \%$ (s.d. $=0.86)$, and average return on assets was $-9 \%($ s.d. $=0.96)$.

Insert Table 3 about here 
The mean network size in 1995 was 34 persons $($ s.d. $=9.42)$. The mean heterophily was $82 \%($ s.d. $=0.06)$ whereas homophily was $18 \%($ s.d. $=0.06)$. A typical entrepreneur had 12 friends (s.d. = 4.7) and 22 acquaintances $($ s.d. $=6.5)$. The mean of resource-rich ties was 16 (s.d. $=6.6)$, and $41 \%$ of entrepreneurs $($ s.d. $=0.49)$ had mobilized financial resources.

The figures in Table 3 suggest that changes in all network indicators except homophily $(\mathrm{x}=-5$, s.d. $=0.11)$ and strong ties $(\mathrm{x}=-6$, s.d. $=5.7)$ are positive. Thus, network size $(x=7.3$, s.d. $=11.6)$, heterophily $(x=5$, s.d. $=0.11)$, weak ties $(x=13$, s.d. $=9.69)$ and resourcefulness $(\mathrm{x}=4$, s.d. $=8.05)$ have increased over four years.

\section{Network Dynamics}

Table 4 provides the results of the multivariate regression predicting changes in network size as a function of initial network attributes, controlling for industry, firm size, firm origin and region. Considering the significant correlation coefficients, I included initial network size and resourcefulness as independent variables in the regression analysis.

Insert Table 4 here

The baseline model (1) includes industry dummies, size dummies, new venture dummy, and region dummies. Petrozavodsk dummy, resource sector dummy, medium size dummy, and privatized firm dummy were excluded in the regression analysis because of their overall weak contribution to the model. Model 1 is not significant. Model 2 shows that initial network size $(B=-0.77, p<0.001)$ is negatively related to changes in network size, and the overall model is also significant $\left(\mathrm{F}=5.40, \mathrm{R}^{2}=0.44\right)$. Model 3 
reveals that initial network resourcefulness $(B=-0.95, \mathrm{p}<0.001)$ is negatively associated with changes in network size. The model is significant $\left(\mathrm{F}=3.62, \mathrm{R}^{2}=0.34\right)$. Models 2 and 3 illustrate that trade and manufacturing dummies are associated significantly and positively with increase in network size over time. Model 4 examines the two independent variables with size, new venture and region dummies. The model indicates that network size $(B=-0.96, p<0.05)$ and new venture dummy $(B=-6.13, p<0.05)$ have strong negative impacts on network size increase. The overall model is significant $(\mathrm{F}=$ $3.28, \mathrm{p}<0.05)$.

Insert Table 5 about here

Table 5 presents the results of regression analysis predicting network dynamics (other than size) as a function of initial networks and original occupational status, controlling for industry, firm size, and firm origin. Region dummies were excluded in regressions because of their weak contributions to the model. Model 1 demonstrates that initial network heterophily $(\mathrm{B}=-1.04, \mathrm{p}<0.01$ ) has a significant but negative impact on changes in heterophily, and the model is significant $\left(F=7.24, \mathrm{R}^{2}=0.51\right)$. Model 2 shows that network homophily $(\mathrm{B}=-1.04, \mathrm{p}<0.001)$ is negatively associated with increase in homophily, and the model is also significant $\left(\mathrm{F}=7.24, \mathrm{R}^{2}=0.51\right)$. Models 3 and 4 report that network size $(B=-0.47, p<0.01)$ and resourcefulness $(B=-0.55, p<0.001)$ negatively affect changes in strong ties. Both models are significant $\left(F=8.71, \mathrm{R}^{2}=0.56, \mathrm{~F}=4.35\right.$, $\left.\mathrm{R}^{2}=0.38\right)$

Models 5, 6 and 7 in Table 5 reveal that network size $(B=-0.36, p<0.01)$, resourcefulness $(\mathrm{B}=-0.59, \mathrm{p}<0.001)$, and occupational status $(\mathrm{B}=-0.02, \mathrm{p}<0.5)$ are 
negatively associated with changes in resourcefulness. Model $5\left(\mathrm{~F}=3.19, \mathrm{R}^{2}=0.31\right)$ and model $6\left(\mathrm{~F}=3.88, \mathrm{R}^{2}=0.36\right)$ are significant whereas model 7 is not. Model 8 indicates that network size $(\mathrm{B}=0.01, \mathrm{p}<0.05)$ is associated positively with resources mobilized 99 , and the model is significant $\left(F=2.29, \mathrm{R}^{2}=0.25\right)$.

Among control variables, trade and manufacturing dummies are significantly correlated to changes in network variables, and all associations except change in heterophily are positive.

Insert Table 6 about here

Table 6 provides the results of regression analysis predicting network dynamics as a function of firm performance, controlling for industry and firm size. Models 1 and 2 demonstrate that the average sales growth $(\mathrm{B}=-11.11, \mathrm{p}<0.5)$ and return on assets $98(\mathrm{~B}$ $=-2.34, \mathrm{p}<0.5)$ negatively affect increase in network size although both models are insignificant. Model 3 reveals that the average profit margin $(B=-0.03, p<0.5)$ has a significant but negative impact on changes in network heterophily, and the model is significant $(F=3.03, \mathrm{p}<0.5)$. Model 4 shows that the average profit margin $(B=0.03$, $\mathrm{p}<0.5)$ is positively correlated to change in homophily, and the model is significant $(\mathrm{F}=$ 3.03, $\mathrm{p}<0.5)$. Models 5, 6 and 7 indicate that the average sales growth $(\mathrm{B}=-10.78$, $\mathrm{p}<0.5)$, sales growth $97(\mathrm{~B}=-6.16, \mathrm{p}<0.5)$, and sales growth $98(\mathrm{~B}=--6.68, \mathrm{p}<0.5)$ negatively affect changes in weak ties although all three models are insignificant. Models 8 and 9 confirm that sales growth $98(\mathrm{~B}=-6.16, \mathrm{p}<0.5)$ and the average sales growth $(\mathrm{B}$ $=-7.04, \mathrm{p}<0.5)$ do influence negatively increase in network resourcefulness, and the models are insignificant. 


\section{DISCUSSION}

The decline in number of friends is consistent with the general trend of declining trust in interpersonal relationships among the Russians (Ledeneva, 1998: 195). It may be speculated that taking advantage of spotted opportunities in friendship ties pressurizes relationships that result in friends' flee (Burt, 1992). An alternative explanation for the finding may be that entrepreneurs become calculative and less friendly species over time due to the time pressure and work overload.

The decreased homophily in entrepreneurs' network reveals that as business develops various needs rise, and these needs force entrepreneurs to diversify their personal and business networks.

Original network range predicts network changes in a reverse manner: the greater the original network range the less the increase in structural, relational and resource elements of entrepreneurs' networks. The hypotheses H1a, H1b and H1c are not affirmative. This finding suggests that there is a ceiling effect on network dynamics: the actual number of ties that could be managed by a person limits the absolute number of contacts in any personal networks.

Original occupational status has a limited explanatory power for network dynamics. Although the variable affects significantly and negatively changes in resourcefulness, the overall finding does not support hypotheses $\mathrm{H} 2 \mathrm{a}, \mathrm{H} 2 \mathrm{~b}$ and $\mathrm{H} 2 \mathrm{c}$. The evidence demonstrates that initial high status does not provide advantages in network building, and structural barriers, therefore, do not hamper active networking. The finding that the higher the original social status the less the increase in resourcefulness seems to suggest that high status entrepreneurs already do possess resource-rich networks, and 
therefore, they are conservative in networking whereas low status entrepreneurs seem to seek out resource-rich contacts.

Industry may predict network changes: trade and manufacturing entrepreneurs increased their network range. The nature of trading that the greater the number of acquaintances the greater the number of potential buyers and suppliers who are socially bound seems to be the case in Russia. The finding on manufacturing may be countryspecific: Russian manufacturing plants are hugely indebted and inter-enterprise arrears are prevalent, and therefore, many entrepreneurs deliberately look for new and better clients and business partners.

Entrepreneurial performance has differentiated effects on structural changes in networks: increase in size and heterophily are conversely affected by performance whereas homophily is positively affected by performance. Hypotheses $\mathrm{H} 3 \mathrm{a}$ and $\mathrm{H} 3 \mathrm{~b}$ are confirmed, and hypothesis $3 \mathrm{c}$ is not supported. The assumption that performance success motivates entrepreneurs to preserve their networks (size and heterophily) whereas failure leads to more active networking seems to have some empirical ground in Russia at least. The evidence that average profit margin predicts homophily increase suggests those who buy at cheaper prices and sell at higher margins network more actively with entrepreneurs of the same industry because of the information and other benefits about the market dynamics.

Sales growth predicts decrease in weak ties while strong ties are unaffected. Hypothesis $\mathrm{H} 4 \mathrm{a}$ is not affirmative but hypothesis $\mathrm{H} 4 \mathrm{~b}$ is confirmed. Successful entrepreneurs may stick to their old embedded weak ties whereas less successful ones recruit more and more weak ties to create new opportunities. 
The findings on the relationship between firm performance and resource dynamics of networks are mixed: hypothesis $\mathrm{H} 5 \mathrm{a}$ is supported whereas hypothesis $\mathrm{H} 5 \mathrm{~b}$ is not confirmed. Well-do entrepreneurs do not "chase" resource-rich new ties whereas those who are lagging behind enrich their social capital by engaging in relationships with powerful alters. Sales growth or higher profit margin does not affect the volume of mobilized resources.

\section{CONCLUSION}

The dynamics of social capital is determined by the initial state of personal networks and firm performance: the better the initial network and firm performance the less the likelihood of increase in various elements of entrepreneurs' social capital. Successful entrepreneurs are more likely to conserve their networks whereas less successful ones are likely expand their personal networks.

Several limitations should be emphasized. The sample size is relatively small, and therefore, one should be cautious of over-generalization of the results. The research site is Russia, which is going through simultaneous social, economic and political crises, and therefore, this limits the generalizability of the findings to more stable Western societies.

The research implies that further research should focus on how persistent/conservative networking behaviour of successful entrepreneurs affects firms' performance over time. The practical implication is that entrepreneurs should be aware of the influences of firm performance or venture life-cycle on their social behaviour such as networking. 


\section{REFERENCES}

Abell, Peter. 1996. "Self-employment and entrepreneurship. A study of entry and exit." Pp. 175-206 in James Coleman edited by J. Clark, London: Falmer Press.

Aldrich, Howard. 1982. "The origins and persistence of social networks: A comment." Pp. 281-293 in Social structure and network analysis, edited by P. Marsden and N. Lin, Sage.

Aldrich, Howard. \& Zimmer, Catherine. 1986. "Entrepreneurship through social networks." Pp. 3-23 in The art and science of entrepreneurship edited by D. Sexton and R. Smilor. Cambridge, Mass: Ballinger Publishing.

Anheier, Helmut, Gerhards, Jurgen, \& Romo, Frank, 1995. "Forms of capital and social structure in cultural fields: Examining Bourdieu's social topography." American Journal of Sociology, 100 (4): 859-903.

Baker, Wayne. 1984. "The social structure of a national securities market." American Journal of Sociology, 89 (4): 775-811.

- 1990. Market networks and corporate behavior. American Journal of Sociology, 96 (3): 589-625.

Bean, Fank. \& Bell-Rose, Stephanie. 1999. Immigration and opportunity: Race, Ethnicity, and Employment in the United States, New York: Russel Sage Foundation.

Belliveau, Maura, O'Reilly, Charles, \& Wade, James. "Social capital at the top: Effects of social similarity and status on CEO compensation." Academy of Management Journal, 39(6): 1568-1593.

Berliner, Joseph. 1957. Factory and manager in the USSR, Cambridge, MA: Harvard University Press.

Birley, Sue. 1985. "The role of networks in the entrepreneurial process.” Journal of Business Venturing, 1(1): 107-117.

Bourdieu, Pierre, 1986. "The forms of capital. Pp. 241-258. Handbook of theory and research for the sociology of education New York: Greenwood.

Burt, Ronald. 1983a. "Distinguishing relational contents." Pp. 35-74. Applied network analysis, A methodological introduction edited by R. Burt and M. Minor. London: Sage.

- 1983b. Range. Pp. 176-194. Applied network analysis, A methodological introduction edited by R. Burt and M. Minor. London: Sage.

- 1992. Structural holes, The social structure of competition, Cambridge: Harvard 
— 1997a. "The contingent value of social capital." Administrative Science Quarterly, 42: 339-365.

Coleman, James. 1988. "Social capital in the creation of human capital." American Journal of Sociology, 94: S95-S120.

Earle, John, Estrin, Saul, \& Leshchenko, Larisa, 1996. "Ownership structures, patterns of control, and enterprise behaviour in Russia." Pp. 205-252. In Enterprise restructuring and economic policy in Russia edited by S. Commander, Q. Fan \& M. Schaffer, the World Bank.

Galunic, Charles. \& Moran, Peter. 1999. Social capital and productive exchange: Structural and relational embeddedness and managerial performance link. Manuscript.

Granovetter, Mark. 1985. "Economic action and social structure: The problem of embeddedness." American Journal of Sociology, 91 (3): 481-510.

- 1990. "The old and the new economic sociology: A history and an agenda." Pp. 89112. Beyond the market place: Rethinking economy and society edited by R. Friedland \& A. Robertson, New York: Walter de Gruyter.

Ibarra, Herminia. 1992. "Homophily and differential returns: Sex differences in network structure and access in an advertising firm." Administrative Science Quarterly, 37: 422447.

— 1993. "Personal networks of women and minorities in management: a conceptual framework." Academy of Management Review, 18 (1): 56-87

Johannisson, Bengt. 1996. "The dynamics of entrepreneurial networks." Pp. 253-267. Frontiers of Entrepreneurship Research: 253-267.

Kosova, Larisa. 1999. "Den'gi ili vlast'?" Monitoring obshchestvennogo mneniya, 41 (3): 24-26.

Krackhardt, David. 1990. "Assessing the political landscape: structure, cognition, and power in organizations." Administrative Science Quarterly, 35: 342-369.

— 1992. "The strength of strong ties: The importance of philos in organizations." Pp. 216-239. Networks and organizations: Structure, form, and action edited by N. Nohria \& R. Eccles. Cambridge, Mass: Harvard Business School Press.

Lai, Gina. Lin, Nan. \& Leung, Shu-Yin. 1998. "Network resources, contact resources and status attainment." Social Networks, 20: 159-178.

Lapidus, Mikhail. \& van de Waal-Palms, P. 1997. Understanding Russian banking, Mir. 
Larson, Andrea. 1992. "Network dyads in entrepreneurial settings: A study of the governance of exchange relationships." Administrative Science Quarterly, 37: 76-104.

Ledeneva, Alena. 1998. Russia's economy of favours: Blat, networking and informal exchange, Cambridge: Cambridge University Press.

Light, Ivan. \& Isralowitz, Richard. 1997. Immigrant entrepreneurs and immigrant absorption in the United States and Israel, Ashgate.

Lin, Nan, 1990. "Social Resources and Social Mobility: A Structural Theory of Status Attainment", Pp. 247-271 in R. Breiger, (ed.), Social Mobility and Social Structure, Cambridge: Cambridge University Press.

Lin, Nan. \& Dumin, Mary. 1986. "Access to occupations through social ties." Social Networks, 8: 365-385.

Lin, Nan, Vaughn, John. \& Ensel, Walter. 1981. "Social resources and occupational status attainment." Social Forces, 59(4): 1163-81.

March J. \& Sutton, R. 1997. "Organizational performance as a dependent variable." Organisation Science, 8 (6): 698-706.

Marsden, Peter. 1987. "Core discussion networks of Americans." American Sociological Review, 52: 122-131.

— 1990. "Network data and measurement." Annual Review of Sociology, 16: 435-463.

Marsden, Peter. \& Campbell, Karen. 1984. "Measuring tie strength.” Social Forces, 63 (2): 482-501.

Marsden, Peter. \& Hurlbert, Jeanne. 1988. "Social resources and mobility outcomes: A replication and extension." Social Forces, 67: 1038-1059.

Meyer, M. 1994. "Measuring performance in economic organisations". In The Handbook of Economic Sociology ed. N. Smelser and R. Swedberg, 556-578, Princeton: Princeton University Press.

Moore, Glen. 1990. "Structural determinants of men's and women's personal networks." American Sociological Review, 55: 726-735.

Nahapiet, Janine. \& Ghoshal, Sumantra. 1998. "Social capital, intellectual capital, and organisational advantage." Academy of Management Review, 23 (2): 242-266.

Nohria, Nitin. 1992. "Information and search in the creation on new business ventures: the case of the 128 venture group, Pp. 240-261. Networks and organizations: Structure, form, and action, edited by N. Nohria \& R. Eccles, Boston: Harvard Business School 
Podolny, Joel. \& Baron, James. 1997. "Resources and relationships: social networks and mobility in the work place." American Sociological Review, 62: 673-693.

Podolny, Joel. \& Page, Karen. 1998. "Network forms of organization." Annual Review of Sociology, 24: 57-76.

Portes, Alejandro. 1998. "Social capital: Its origin and applications in modern sociology." Annual Review of Sociology, 24: 1-24.

Renzulli, Linda. Aldrich, Howard. \& Moody, James. 1999. Family matters: Gender, networks, and entrepreneurial outcomes, Manuscript. Department of Sociology, University of North Carolina at Chapel Hill.

Rossiiskaya federatsiya. 1995. Zakon o gosudarstvennoi podderzhke malogo predprinimatel'stva, Moscow.

Shane, Scott. \& Cable, Daniel. 1999. "Social capital and the financing of new ventures," manuscript, MIT Sloan School of Management.

Shkaratan, Ovsei. \& Figatner, Yurii. 1992. Starye i novye khozyaeva Rossii. Mir Rossii, 1(1): 67-90.

Steier, Lloyd. 2000. "Entrepreneurship and the evolution of angel financial networks." Organization Studies, 21 (1): 163-192.

Stinchcombe, Arthur. 1965. "Social structure and organisations". Pp. 142-193. Handbook of organisations edited by J. March. Chicago: Rand McNally.

Stuart, Toby. Hoang, Ha. \& Hybels, Ralph. 1999. "Interorganizational endorsement and the performance of entrepreneurial ventures." Administrative Science Quarterly, 44:315349.

Tsai, Wenpin. \& Ghoshal, Sumantra. 1998. "Social capital and value creation: The role of intrafirm networks.” Academy of Management Journal, 41 (4): 464-476.

Uzzi, Brian. 1996. "The sources and consequences of embeddedness for the economic performance of organisations: The network effect." American Sociological Review, 61: 674-698.

- 1997. "Social structure and competition in interfirm networks: The paradox of embeddedness." Administrative Science Quarterly, 42: 35-67.

Walker, Gordon. Kogut, Bruce. \& Shan, Weijan. 1997. "Social capital, structural holes, and the formation of an industry network." Organization Science, 8(2): 109-125. 
TABLE 1

The Number of Entrepreneurs Interviewed in 1995

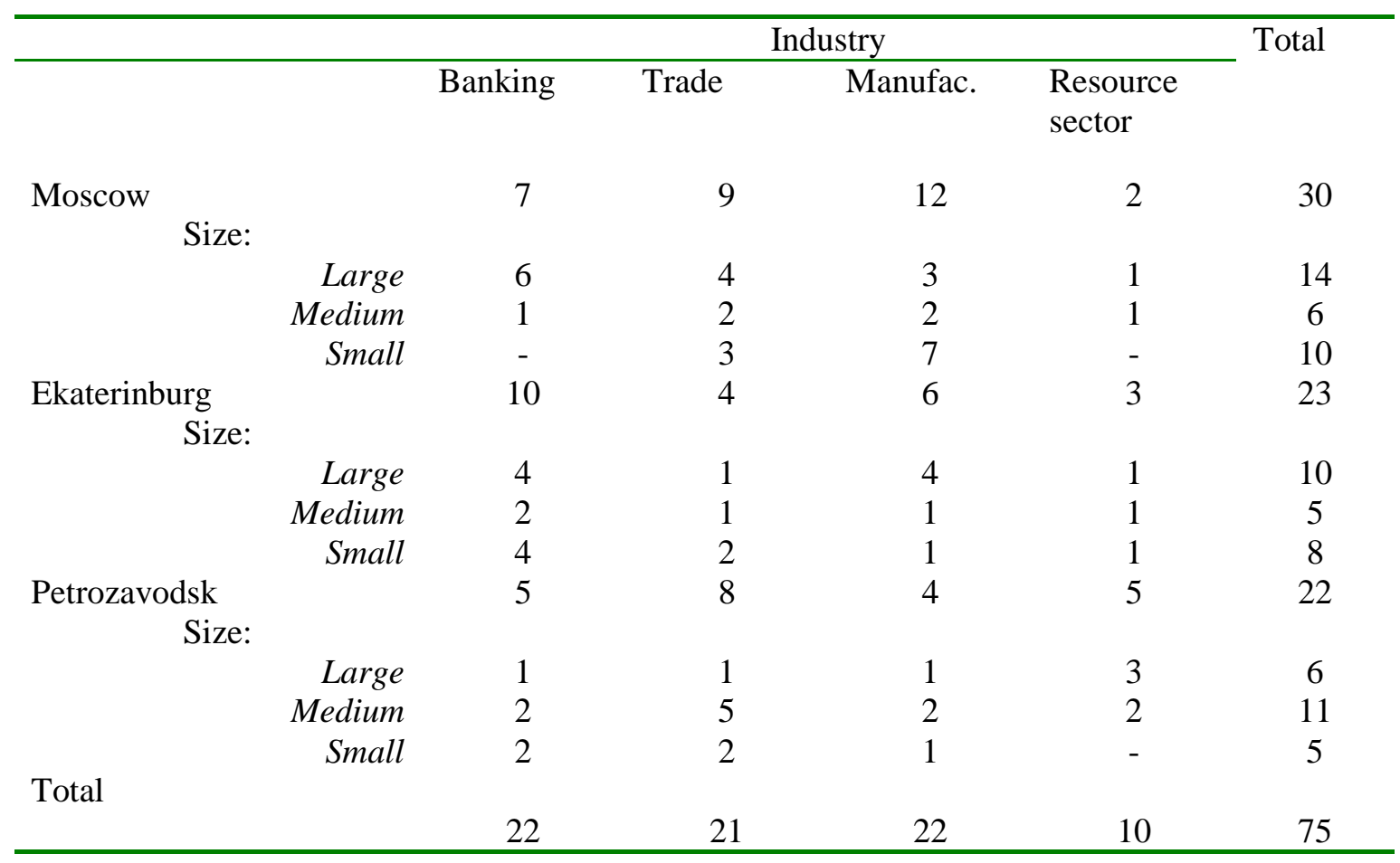

TABLE 2

Follow-up Interviews in 1999

\begin{tabular}{llc}
\hline & "Location" after 4 years & \\
\hline No-Contact: & Murdered & 9 \\
& Committed suicide & 2 \\
& Left the country & 1 \\
& Hiding from criminal charges & 2 \\
& Unreachable & 2 \\
& & 2 \\
Not in Business: & Hired middle managers & 7 \\
& Civil servant & 2 \\
& Local politician & 1 \\
& Unemployed & 1 \\
& Retired & 1 \\
& & 1 \\
In Business: & Refusal & 59 \\
& Interviewed & 3 \\
& & 56 \\
\hline
\end{tabular}


TABLE 3

Means, Standard Deviations and Pearson's Correlations

\begin{tabular}{|c|c|c|c|c|c|c|c|c|c|}
\hline & Variables & $\mathbf{M}$ & SD & 1 & 2 & 3 & 4 & 5 & 6 \\
\hline 1 & Network size & 34.4 & 9.42 & & & & & & \\
\hline 2 & $\begin{array}{l}\text { Change in network } \\
\text { size }\end{array}$ & 7.3 & 11.6 & $-.52 \mathbb{I}$ & & & & & \\
\hline 3 & Network heterophily & 0.82 & 0.06 & .06 & -.03 & & & & \\
\hline 4 & $\begin{array}{l}\text { Change in network } \\
\text { heterophily }\end{array}$ & 0.05 & 0.11 & -.05 & -.10 & $-.61 \Phi$ & & & \\
\hline 5 & Network homophily & 0.18 & 0.06 & -.06 & .03 & $-1 \Phi$ & $.61 \Phi$ & & \\
\hline 6 & $\begin{array}{l}\text { Change in network } \\
\text { homophily }\end{array}$ & -0.05 & 0.11 & .05 & .10 & $.61 \Phi$ & $-1 \Phi$ & $-.61 \Phi$ & \\
\hline 7 & Strong ties & 12 & 4.70 & $.78 \mathbb{I}$ & $-.48 *$ & .04 & -.00 & -.04 & .00 \\
\hline 8 & Change in strong ties & -6 & 5.70 & -.669 & .56 II & -.03 & -.02 & .03 & .02 \\
\hline 9 & Weak ties & 22 & 6.44 & $.89 \pi$ & $-.40 \mathrm{I}$ & .05 & -.10 & -.05 & .10 \\
\hline 10 & Change in weak ties & 13 & 9.69 & -.23 & $.87 \Phi$ & -.01 & -.11 & .01 & .11 \\
\hline 11 & Resourcefulness & 16 & 6.6 & $.88 \mathbb{1}$ & -.46 II & .07 & -.03 & -.07 & .03 \\
\hline 12 & $\begin{array}{l}\text { Change in } \\
\text { resourcefulness }\end{array}$ & 4 & 8.05 & $-.39 \mathbb{I}$ & $.72 \pi$ & -.17 & .01 & .17 & -.01 \\
\hline 13 & $\begin{array}{l}\text { Resources mobilized } \\
95\end{array}$ & 0.41 & 0.49 & .18 & -.02 & .15 & -.10 & -.15 & .10 \\
\hline 14 & $\begin{array}{l}\text { Resources mobilized } \\
99\end{array}$ & 0.30 & 0.46 & $.33^{*}$ & .03 & -.01 & -.19 & .01 & .19 \\
\hline 15 & Occupational status & 1.9 & 0.81 & $.48 \pi$ & -.19 & -.06 & -.15 & .06 & .15 \\
\hline 16 & Sales growth 96 & 0.19 & 0.58 & .08 & -.21 & -.07 & -.10 & .07 & .10 \\
\hline 17 & Sales growth 97 & 0.04 & 0.37 & -.06 & -.21 & .08 & -.12 & -.08 & .12 \\
\hline 18 & Sales growth 98 & -0.19 & 0.43 & .20 & -.22 & -.12 & .13 & .12 & -.13 \\
\hline 19 & Average sales growth & 0.01 & 0.33 & .11 & $-.30 *$ & -.06 & -.05 & .06 & .05 \\
\hline 20 & Profit margin 95 & -0.32 & 2.66 & -.04 & .01 & -.05 & .02 & .05 & -.02 \\
\hline 21 & Profit margin 96 & -0.32 & 1.85 & -.05 & -.02 & .01 & -.10 & -.01 & .10 \\
\hline 22 & Profit margin 97 & -0.71 & 3.23 & -.10 & .03 & -.10 & -.05 & .10 & .05 \\
\hline 23 & Profit margin 98 & -0.46 & 1.16 & .27 & -.14 & .26 & -.24 & -.26 & .24 \\
\hline 24 & $\begin{array}{l}\text { Average profit } \\
\text { margin }\end{array}$ & -0.22 & 0.86 & .04 & -.07 & .15 & $-.34 *$ & -.15 & $.34 *$ \\
\hline 25 & Return on assets 95 & 0.13 & 0.83 & -.04 & -.03 & .25 & -.24 & -.25 & .24 \\
\hline 26 & Return on assets 96 & 0.02 & 1.01 & .12 & -.13 & .13 & -.17 & -.13 & .17 \\
\hline 27 & Return on assets 97 & -0.13 & 0.99 & .16 & -.14 & .08 & -.13 & -.08 & .13 \\
\hline 28 & Return on assets 98 & -0.40 & 1.40 & $.29 *$ & $-.28^{*}$ & -.01 & -.01 & .01 & .01 \\
\hline 29 & $\begin{array}{l}\text { Average return on } \\
\text { assets }\end{array}$ & -0.09 & 0.96 & .17 & -.20 & .10 & -.13 & -.10 & .13 \\
\hline
\end{tabular}


TABLE 3

Means, Standard Deviations and Pearson's Correlations (Con't)

\begin{tabular}{|c|c|c|c|c|c|c|c|c|c|c|c|c|}
\hline & Variables & 7 & 8 & 9 & 10 & 11 & 12 & 13 & 14 & 15 & 16 & 17 \\
\hline 8 & $\begin{array}{l}\text { Change in strong } \\
\text { ties }\end{array}$ & $-.83 \mathbb{I}$ & & & & & & & & & & \\
\hline 9 & Weak ties & $.41 \Phi$ & -.361 & & & & & & & & & \\
\hline 10 & $\begin{array}{l}\text { Change in weak } \\
\text { ties }\end{array}$ & -.09 & .09 & $-.28 *$ & & & & & & & & \\
\hline 11 & Resourcefulness & $.61 \Phi$ & $-.54 \rrbracket$ & $.84 \mathbb{I}$ & -.24 & & & & & & & \\
\hline 12 & $\begin{array}{l}\text { Change in } \\
\text { resourcefulness }\end{array}$ & -.22 & $.31 *$ & $-.40 \Psi$ & $.73 \pi$ & $-.46 \Phi$ & & & & & & \\
\hline 13 & $\begin{array}{l}\text { Resources } \\
\text { mobilized } 95\end{array}$ & .10 & -.15 & .19 & .05 & .17 & -.12 & & & & & \\
\hline 14 & $\begin{array}{l}\text { Resources } \\
\text { mobilized } 99\end{array}$ & .20 & -.07 & $.34 \pi$ & .08 & .16 & .02 & .23 & & & & \\
\hline 15 & $\begin{array}{l}\text { Occupational } \\
\text { status }\end{array}$ & .25 & $-.26^{*}$ & $.52 \pi$ & -.76 & .519 & $-.27 *$ & $.40 \mathrm{I}$ & $.41 \Phi$ & & & \\
\hline 16 & Sales growth 96 & .08 & -.18 & .05 & -.14 & .01 & -.03 & .17 & -.02 & .10 & & \\
\hline 17 & Sales growth 97 & -.16 & .13 & .02 & $-.34 *$ & -.09 & -.25 & .17 & .08 & .26 & $.32 *$ & \\
\hline 18 & Sales growth 98 & .00 & .01 & $.29 *$ & $-.28 *$ & $.27 *$ & $-.37 \Phi$ & $.35^{*}$ & .15 & $.44 I$ & .03 & $.48 \mathbb{I}$ \\
\hline 19 & $\begin{array}{l}\text { Average sales } \\
\text { growth }\end{array}$ & -.00 & -.05 & .16 & $-.34^{*}$ & .09 & $-.28^{*}$ & $.32 *$ & .09 & $.35 \mathrm{II}$ & $.72 \Phi$ & $.78 \mathbb{1}$ \\
\hline 20 & Profit margin 95 & -.15 & .17 & .05 & -.09 & -.03 & -.07 & -.13 & .10 & .19 & -.06 & $.27 *$ \\
\hline 21 & Profit margin 96 & -.13 & .05 & .01 & -.05 & -.09 & -.01 & -.17 & .16 & .10 & .16 & .23 \\
\hline 22 & Profit margin 97 & -.19 & .17 & -.02 & -.06 & -.14 & -.04 & -.23 & .18 & .19 & .06 & $.32 *$ \\
\hline 23 & Profit margin 98 & .09 & -.20 & $.33 *$ & -.05 & .20 & -.19 & .03 & $.29 *$ & .26 & -.06 & .20 \\
\hline 24 & $\begin{array}{l}\text { Average profit } \\
\text { margin }\end{array}$ & -.02 & -.13 & .07 & -.01 & -.08 & -.06 & -.10 & .25 & .14 & .22 & .20 \\
\hline 25 & $\begin{array}{l}\text { Return on assets } \\
95\end{array}$ & -.00 & -.06 & -.06 & -.00 & -.06 & -.11 & .17 & .04 & .12 & -.03 & .13 \\
\hline 26 & $\begin{array}{l}\text { Return on assets } \\
96\end{array}$ & .07 & -.17 & .13 & -.06 & .06 & -.15 & .21 & .17 & .17 & .15 & .17 \\
\hline 27 & $\begin{array}{l}\text { Return on assets } \\
97\end{array}$ & .06 & -.12 & .18 & -.22 & .07 & -.21 & .18 & .17 & .21 & .19 & $.34 *$ \\
\hline 28 & $\begin{array}{l}\text { Return on assets } \\
98\end{array}$ & .17 & -.24 & $.29 *$ & -.20 & .20 & -.04 & .21 & .25 & .18 & .18 & .20 \\
\hline 29 & $\begin{array}{l}\text { Average return } \\
\text { on assets }\end{array}$ & .09 & -.17 & .17 & -.14 & .09 & -.18 & .21 & .19 & .19 & .14 & .23 \\
\hline
\end{tabular}


TABLE 3

Means, Standard Deviations and Pearson's Correlations (Con't)

\begin{tabular}{|c|c|c|c|c|c|c|c|c|c|c|c|c|}
\hline & Variables & 18 & 19 & 20 & 21 & 22 & 23 & 24 & 25 & 26 & 27 & 28 \\
\hline 19 & $\begin{array}{l}\text { Average } \\
\text { sales growth }\end{array}$ & $.64 \pi$ & & & & & & & & & & \\
\hline 20 & $\begin{array}{l}\text { Profit margin } \\
95\end{array}$ & .27 & .18 & & & & & & & & & \\
\hline 21 & $\begin{array}{l}\text { Profit margin } \\
96\end{array}$ & .01 & .19 & $.81 \Phi$ & & & & & & & & \\
\hline 22 & $\begin{array}{l}\text { Profit margin } \\
97\end{array}$ & .15 & .22 & $.83 \pi$ & $.87 \mathbb{I}$ & & & & & & & \\
\hline 23 & $\begin{array}{l}\text { Profit margin } \\
98\end{array}$ & $.30 *$ & .16 & .18 & .36 II & .26 & & & & & & \\
\hline 24 & $\begin{array}{l}\text { Average } \\
\text { profit margin }\end{array}$ & -.05 & .19 & .40I & $.82 \mathbb{I}$ & $.87 \Phi$ & $.62 \pi$ & & & & & \\
\hline 25 & $\begin{array}{l}\text { Return on } \\
\text { assets } 95\end{array}$ & .25 & .14 & .24 & .24 & .19 & $.32 *$ & $.28 *$ & & & & \\
\hline 26 & $\begin{array}{l}\text { Return on } \\
\text { assets } 96\end{array}$ & .24 & .26 & .21 & $.32 *$ & .22 & .46 II & .411 & $.82 \pi$ & & & \\
\hline 27 & $\begin{array}{l}\text { Return on } \\
\text { assets } 97\end{array}$ & $.39 \pi$ & .41 II & .14 & .24 & .25 & .479 & .479 & $.75 \Phi$ & .879 & & \\
\hline 28 & $\begin{array}{l}\text { Return on } \\
\text { assets } 98\end{array}$ & $.38 \mathbb{I}$ & $.35^{*}$ & .00 & .10 & .03 & $.50 \mathrm{I}$ & $.32 *$ & $.59 \pi$ & .79爪 & $.90 \pi$ & \\
\hline 29 & $\begin{array}{l}\text { Average } \\
\text { return on } \\
\text { assets }\end{array}$ & .35 II & $.33^{*}$ & .14 & .23 & .17 & $.49 \mathrm{II}$ & .40I & $.83 \mathbb{I}$ & .94 II & $.96 \mathrm{I}$ & $.92 \mathbb{I}$ \\
\hline
\end{tabular}

Two-tailed tests.

$* p<0.5$

$\mathbb{I} p<0.01$ 
TABLE 4

Regression Analysis Predicting Increase in Network Size as Function of Initial Networks $(\mathrm{N}=56)$

\begin{tabular}{|c|c|c|c|c|}
\hline & Model 1 & Model 2 & Model 3 & Model 4 \\
\hline \multicolumn{5}{|l|}{ Industry dummies } \\
\hline Banking & $\begin{array}{l}9.42 \\
(5.86)\end{array}$ & $\begin{array}{l}10.88 \\
(4.35)\end{array}$ & $\begin{array}{l}9.80 \\
(4.69)\end{array}$ & \\
\hline Trade & $\begin{array}{c}5.57 \\
(5.42)\end{array}$ & $\begin{array}{l}12.25 \mathrm{I} \\
(4.41)\end{array}$ & $\begin{array}{l}9.64 * \\
(4.67)\end{array}$ & \\
\hline Manufacturing & $\begin{array}{l}5.48 \\
(5.57)\end{array}$ & $\begin{array}{l}12.22 \text { I } \\
(4.43)\end{array}$ & $\begin{array}{l}10.9^{*} \\
(4.78)\end{array}$ & \\
\hline \multicolumn{5}{|l|}{ Size dummies } \\
\hline Small & $\begin{array}{c}2.69 \\
(3.99)\end{array}$ & $\begin{array}{l}-1.10 \\
(3.19)\end{array}$ & $\begin{array}{l}-1.01 \\
(3.48)\end{array}$ & $\begin{array}{c}2.17 \\
(3.37)\end{array}$ \\
\hline Large & $\begin{array}{l}-0.18 \\
(4.01)\end{array}$ & $\begin{array}{l}1.23 \\
(3.14)\end{array}$ & $\begin{array}{c}1.48 \\
(3.40)\end{array}$ & $\begin{array}{c}0.22 \\
(3.40)\end{array}$ \\
\hline $\begin{array}{l}\text { New venture } \\
\text { dummy } \\
\text { Region dummies }\end{array}$ & $\begin{array}{l}-5.55 \\
(3.59)\end{array}$ & $\begin{array}{l}-5.96 \\
(2.67)\end{array}$ & $\begin{array}{l}-4.90 \\
(2.90)\end{array}$ & $\begin{array}{l}-6.13^{*} \\
(2.98)\end{array}$ \\
\hline Moscow & $\begin{array}{l}-0.95 \\
(4.33)\end{array}$ & & & $\begin{array}{c}2.77 \\
(3.59)\end{array}$ \\
\hline Ekaterinburg & $\begin{array}{l}-1.97 \\
(4.45)\end{array}$ & & & $\begin{array}{l}-0.55 \\
(3.82)\end{array}$ \\
\hline $\begin{array}{l}\text { Independent } \\
\text { variables }\end{array}$ & & & & \\
\hline Network size & & $\begin{array}{l}-0.77 \ddagger \\
(0.14)\end{array}$ & & $\begin{array}{l}-0.96^{*} \\
(0.39)\end{array}$ \\
\hline Resourcefulness & & & $\begin{array}{l}-0.95 \$ \\
(0.22)\end{array}$ & $\begin{array}{c}0.01 \\
(0.47)\end{array}$ \\
\hline Model $F$ & 0.78 & $5.40 \ddagger$ & $3.62 \mathbb{I}$ & $3.28 *$ \\
\hline$R^{2}$ & 0.11 & 0.44 & 0.34 & 0.35 \\
\hline
\end{tabular}

Values represent unstandardized coefficients; standard errors are in parentheses.

$* p<.05$

II $p<.01$

$\$ p<.001$ 
TABLE 5

Regression Analysis Predicting Network Dynamics as Function of Initial Networks and Social Status $(\mathbf{N}=56)$

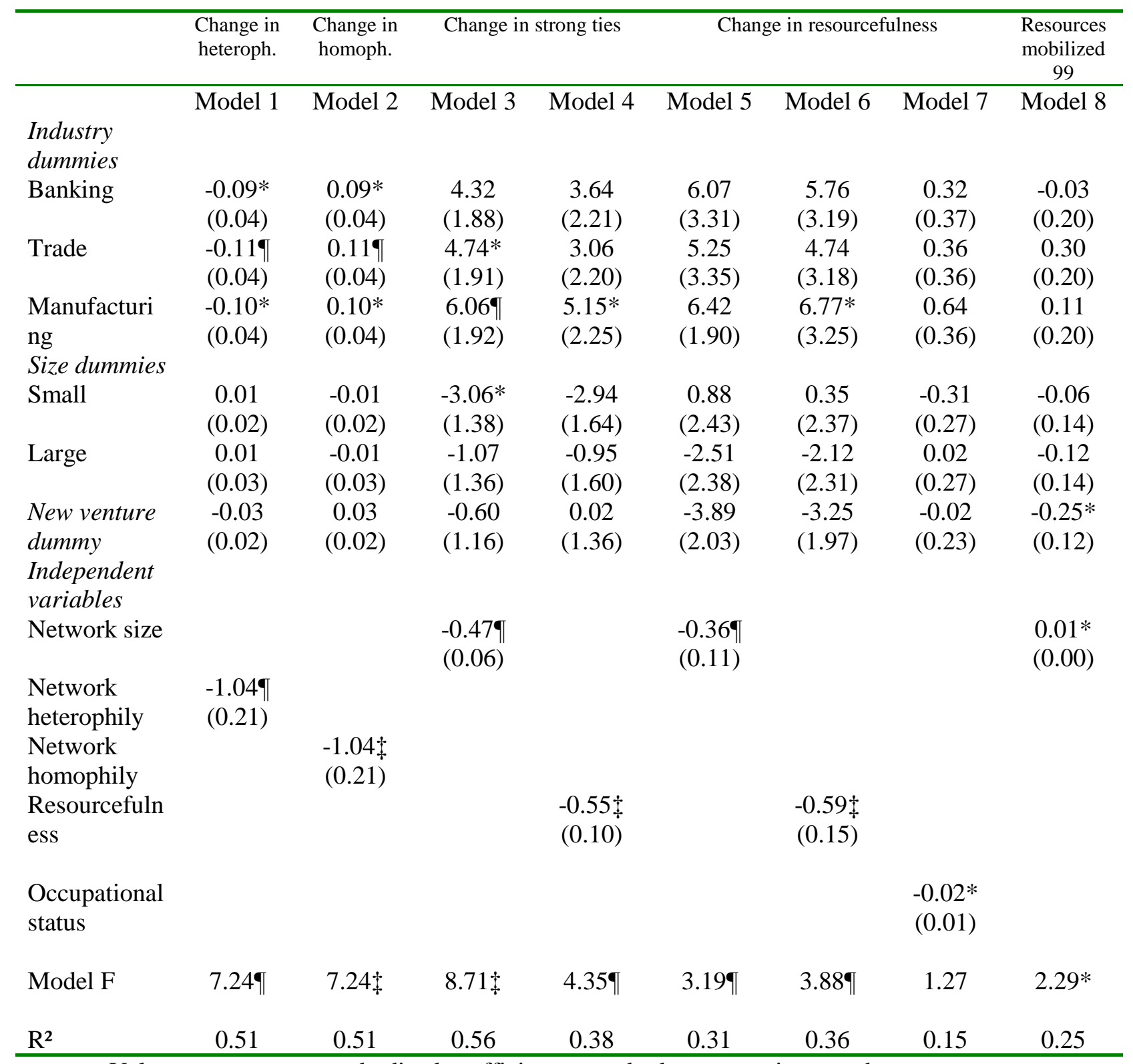

Values represent unstandardized coefficients; standard errors are in parentheses.

$* p<.05$

II $p<.01$

$\ddagger p<.001$ 
TABLE 6

Regression Analysis Predicting Network Dynamics as Function of Firm Performance $(\mathrm{N}=56)$

\begin{tabular}{|c|c|c|c|c|c|c|c|c|c|}
\hline & \multicolumn{2}{|c|}{$\begin{array}{l}\text { Change in } \\
\text { network size }\end{array}$} & \multirow{2}{*}{$\begin{array}{c}\begin{array}{c}\text { Change } \\
\text { in } \\
\text { heterop }\end{array} \\
\text { Model }\end{array}$} & \multirow{2}{*}{$\begin{array}{c}\begin{array}{c}\text { Change } \\
\text { in } \\
\text { homop }\end{array} \\
\text { Model }\end{array}$} & \multicolumn{3}{|c|}{ Change in weak ties } & \multicolumn{2}{|c|}{$\begin{array}{l}\text { Change in } \\
\text { resourcefulness }\end{array}$} \\
\hline & Model & Model & & & Model & Model & Model & Model & Model \\
\hline & 1 & 2 & 3 & 4 & 5 & 6 & 7 & 8 & 9 \\
\hline $\begin{array}{l}\text { Industry } \\
\text { dummies }\end{array}$ & & & & & & & & & \\
\hline Banking & $\begin{array}{c}5.51 \\
(6.03)\end{array}$ & $\begin{array}{c}5.20 \\
(6.18)\end{array}$ & $\begin{array}{l}-0.10 \\
(0.05)\end{array}$ & $\begin{array}{c}0.10 \\
(0.05)\end{array}$ & $\begin{array}{c}2.24 \\
(4.87)\end{array}$ & $\begin{array}{c}4.55 \\
(4.85)\end{array}$ & $\begin{array}{c}3.43 \\
(4.96)\end{array}$ & $\begin{array}{l}3.15 \\
(3.95)\end{array}$ & $\begin{array}{c}2.52 \\
(4.04)\end{array}$ \\
\hline Trade & $\begin{array}{c}3.09 \\
(5.48)\end{array}$ & $\begin{array}{l}4.83 \\
(6.18)\end{array}$ & $\begin{array}{l}-0.13 * \\
(0.05)\end{array}$ & $\begin{array}{l}0.13^{*} \\
(0.05)\end{array}$ & $\begin{array}{c}1.93 \\
(4.42)\end{array}$ & $\begin{array}{c}3.06 \\
(4.43)\end{array}$ & $\begin{array}{c}2.40 \\
(4.53)\end{array}$ & $\begin{array}{c}1.28 \\
(3.60)\end{array}$ & $\begin{array}{c}1.08 \\
(3.67)\end{array}$ \\
\hline $\begin{array}{l}\text { Manufactur } \\
\text { ing }\end{array}$ & $\begin{array}{c}5.28 \\
(5.49)\end{array}$ & $\begin{array}{c}6.03 \\
(5.57)\end{array}$ & $\begin{array}{l}-0.03 \\
(0.05)\end{array}$ & $\begin{array}{c}0.03 \\
(0.05)\end{array}$ & $\begin{array}{c}2.77 \\
(4.43)\end{array}$ & $\begin{array}{c}3.68 \\
(4.45)\end{array}$ & $\begin{array}{c}3.12 \\
(4.54)\end{array}$ & $\begin{array}{c}3.97 \\
(3.62)\end{array}$ & $\begin{array}{c}3.79 \\
(3.68)\end{array}$ \\
\hline $\begin{array}{l}\text { Size } \\
\text { dummies }\end{array}$ & & & & & & & & & \\
\hline Small & $\begin{array}{c}2.89 \\
(4.09)\end{array}$ & $\begin{array}{l}-0.63 \\
(4.27)\end{array}$ & $\begin{array}{c}0.01 \\
(0.03)\end{array}$ & $\begin{array}{l}-0.01 \\
(0.03)\end{array}$ & $\begin{array}{c}4.08 \\
(3.30)\end{array}$ & $\begin{array}{c}2.54 \\
(3.28)\end{array}$ & $\begin{array}{c}2.67 \\
(3.35)\end{array}$ & $\begin{array}{c}2.22 \\
(2.66)\end{array}$ & $\begin{array}{c}3.17 \\
(2.74)\end{array}$ \\
\hline Large & $\begin{array}{c}1.62 \\
(4.12)\end{array}$ & $\begin{array}{c}0.44 \\
(4.14)\end{array}$ & $\begin{array}{l}-0.08 \\
(0.03)\end{array}$ & $\begin{array}{c}0.08 \\
(0.03)\end{array}$ & $\begin{array}{c}3.74 \\
(3.32)\end{array}$ & $\begin{array}{c}2.40 \\
(3.30)\end{array}$ & $\begin{array}{c}3.95 \\
(3.45)\end{array}$ & $\begin{array}{l}-1.61 \\
(2.75)\end{array}$ & $\begin{array}{l}-2.15 \\
(2.76)\end{array}$ \\
\hline $\begin{array}{l}\text { Independen } \\
\text { t variables }\end{array}$ & & & & & & & & & \\
\hline $\begin{array}{l}\text { Average } \\
\text { sales } \\
\text { growth }\end{array}$ & $\begin{array}{c}- \\
11.11 * \\
(5.05)\end{array}$ & & & & $\begin{array}{c}- \\
10.78^{*} \\
(4.07)\end{array}$ & & & & $\begin{array}{l}-7.04^{*} \\
(3.38)\end{array}$ \\
\hline $\begin{array}{l}\text { Return on } \\
\text { assets } 98\end{array}$ & & $\begin{array}{l}-2.34 * \\
(1.29)\end{array}$ & & & & & & & \\
\hline $\begin{array}{l}\text { Average } \\
\text { profit } \\
\text { margin }\end{array}$ & & & $\begin{array}{l}-0.03 * \\
(0.01)\end{array}$ & $\begin{array}{l}0.03 * \\
(0.01)\end{array}$ & & & & & \\
\hline $\begin{array}{l}\text { Sales } \\
\text { growth } 97\end{array}$ & & & & & & $\begin{array}{l}-6.16^{*} \\
(2.54)\end{array}$ & & & \\
\hline $\begin{array}{l}\text { Sales } \\
\text { growth } 98\end{array}$ & & & & & & & $\begin{array}{l}-6.68 * \\
(3.19)\end{array}$ & $\begin{array}{l}-6.16^{*} \\
(2.54)\end{array}$ & \\
\hline Model F & 1.15 & 0.88 & $3.03 *$ & $3.03 *$ & 1.49 & 1.41 & 1.04 & 1.96 & 1.68 \\
\hline $\mathrm{R}^{2}$ & 0.13 & 0.10 & 0.27 & 0.29 & 0.16 & 0.15 & 0.12 & 0.20 & 0.18 \\
\hline
\end{tabular}

Values represent unstandardized coefficients; standard errors are in parentheses.

$* p<.05$

$\Phi p<.01$

$\$ p<.001$ 


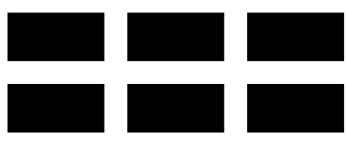

THE WILLIAM DAVIDSON INSTITUTE

AT THE UNIVERSITY OF MICHIGAN BUSINESSSCHOOL

\section{DAVIDSON INSTITUTE WORKING PAPER SERIES}

Working Papers are available at: www.wdi.bus.umich.edu

CURRENT AS OF $12 / 20 / 00$

\begin{tabular}{|c|c|c|}
\hline Publication & Authors & Date \\
\hline $\begin{array}{l}\text { No. } 350 \text { The Dynamics of Entrepreneurial Networks in a Transitional } \\
\text { Economy: The Case of Russia }\end{array}$ & Bat Batjargal & Dec. 2000 \\
\hline $\begin{array}{l}\text { No. } 349 \text { R\&D and Technology Spillovers via FDI: Innovation and } \\
\text { Absorptive Capacity }\end{array}$ & Yuko Kinoshita & Nov. 2000 \\
\hline $\begin{array}{l}\text { No. } 348 \text { Microeconomic aspects of Economic Growth in Eastern } \\
\text { Europe and the Former Soviet Union, } 1950-2000\end{array}$ & Sergei Guriev and Barry W. Ickes & Nov. 2000 \\
\hline $\begin{array}{l}\text { No. } 347 \text { Effective versus Statutory Taxation: Measuring Effective Tax } \\
\text { Administration in Transition Economies }\end{array}$ & $\begin{array}{l}\text { Mark E. Schaffer and Gerard } \\
\text { Turley }\end{array}$ & Nov. 2000 \\
\hline $\begin{array}{l}\text { No. } 346 \text { Objectives and Constraints of Entrepreneurs: Evidence from } \\
\text { Small and Medium Size Enterprises in Russia and Bulgaria }\end{array}$ & $\begin{array}{l}\text { Francesca Pissarides, Miroslav } \\
\text { Singer and Jan Svejnar }\end{array}$ & Oct. 2000 \\
\hline No. 345 Corruption and Anticorruption in the Czech Republic & $\begin{array}{l}\text { Lubomír Lízal and Evžen } \\
\text { Kočenda }\end{array}$ & Oct. 2000 \\
\hline No. 344 The Effects of Direct Foreign Investment on Domestic Firms & Jozef Konings & Oct. 2000 \\
\hline No. 343 On the Identification of Relative Wage Rigidity Dynamics & Patrick A. Puhani & Oct. 2000 \\
\hline $\begin{array}{l}\text { No. } 342 \text { The Determinants of Foreign Direct Investment in Transition } \\
\text { Economies }\end{array}$ & Alan A. Bevan and Saul Estrin & Oct. 2000 \\
\hline No. 341 The Global Spread of Stock Exchanges, 1980-1998 & Klaus Weber and Gerald F. Davis & Nov. 2000 \\
\hline $\begin{array}{l}\text { No. } 340 \text { The Costs and Benefits of Euro-isation in Central-Eastern } \\
\text { Europe Before or Instead of EMU Membership }\end{array}$ & D. Mario Nuti & Oct. 2000 \\
\hline No. 339 Debt Overhang and Barter in Russia & $\begin{array}{l}\text { Sergei Guriev, Igor Makarov and } \\
\text { Mathilde Maurel }\end{array}$ & Sept. 2000 \\
\hline $\begin{array}{l}\text { No. } 338 \text { Firm Performance and the Political Economy of Corporate } \\
\text { Governance: Survey Evidence for Bulgaria, Hungary, Slovakia and } \\
\text { Slovenia }\end{array}$ & $\begin{array}{l}\text { Patrick Paul Walsh and Ciara } \\
\text { Whela }\end{array}$ & July 2000 \\
\hline No. 337 Investment and Instability & $\begin{array}{l}\text { Nauro F. Campos and Jeffrey B. } \\
\text { Nugent }\end{array}$ & May 2000 \\
\hline $\begin{array}{l}\text { No. } 336 \text { The Evolution of the Insurance Sector in Central and } \\
\text { Eastern Europe and the former Soviet Union }\end{array}$ & Robert B.K. Pye & Aug. 2000 \\
\hline $\begin{array}{l}\text { No. } 335 \text { Institutional Technology and the Chains of Trust: Capital } \\
\text { Markets and Privatization in Russia and the Czech Republic }\end{array}$ & Bruce Kogut and Andrew Spicer & Aug. 2000 \\
\hline No. 334 The Evolution of Market Integration in Russia & $\begin{array}{l}\text { Daniel Berkowitz and David N. } \\
\text { DeJong }\end{array}$ & Aug. 2000 \\
\hline No. 333 Efficiency and Market Share in Hungarian Corporate Sector & László Halpern and Gábor Kőrösi & July 2000 \\
\hline No. 332 Search-Money-and-Barter Models of Financial Stabilization & $\begin{array}{l}\text { S.I. Boyarchenko and S.Z. } \\
\text { Levendorskii }\end{array}$ & July 2000 \\
\hline $\begin{array}{l}\text { No. } 331 \text { Worker Training in a Restructuring Economy: Evidence from } \\
\text { the Russian Transition }\end{array}$ & $\begin{array}{l}\text { Mark C. Berger, John S. Earle } \\
\text { and Klara Z. Sabirianova }\end{array}$ & Aug. 2000 \\
\hline $\begin{array}{l}\text { No. } 330 \text { Economic Development in Palanpur 1957-1993: A Sort of } \\
\text { Growth }\end{array}$ & Peter Lanjouw & Aug. 2000 \\
\hline $\begin{array}{l}\text { No. } 329 \text { Trust, Organizational Controls, Knowledge Acquisition from } \\
\text { the Foreign Parents, and Performance in Vietnamese International Joint } \\
\text { Ventures }\end{array}$ & $\begin{array}{l}\text { Marjorie A. Lyles, Le Dang } \\
\text { Doanh, and Jeffrey Q. Barden }\end{array}$ & June 2000 \\
\hline $\begin{array}{l}\text { No. } 328 \text { Comparative Advertising in the Global Marketplace: The } \\
\text { Effects of Cultural Orientation on Communication }\end{array}$ & $\begin{array}{l}\text { Zeynep Gürhan-Canli and } \\
\text { Durairaj Maheswaran }\end{array}$ & Aug. 2000 \\
\hline No. 327 Post Privatization Enterprise Restructuring & Morris Bornstein & July 2000 \\
\hline No. 326 Who is Afraid of Political Instability? & $\begin{array}{l}\text { Nauro F. Campos and Jeffrey B. } \\
\text { Nugent }\end{array}$ & July 2000 \\
\hline
\end{tabular}




\begin{tabular}{|c|c|c|}
\hline No. 325 Business Groups, the Financial Market and Modernization & Raja Kali & June 2000 \\
\hline $\begin{array}{l}\text { No. } 324 \text { Restructuring with What Success? A Case Study of Russian } \\
\text { Firms }\end{array}$ & Susan Linz & July 2000 \\
\hline $\begin{array}{l}\text { No. } 323 \text { Priorities and Sequencing in Privatization: Theory and } \\
\text { Evidence from the Czech Republic }\end{array}$ & $\begin{array}{l}\text { Nandini Gupta, John C. Ham and } \\
\text { Jan Svejnar }\end{array}$ & May 2000 \\
\hline $\begin{array}{l}\text { No. } 322 \text { Liquidity, Volatility, and Equity Trading Costs Across } \\
\text { Countries and Over Time }\end{array}$ & $\begin{array}{l}\text { Ian Domowitz, Jack Glen and } \\
\text { Ananth Madhavan }\end{array}$ & Mar. 2000 \\
\hline $\begin{array}{l}\text { No. } 321 \text { Equilibrium Wage Arrears: A Theoretical and Empirical } \\
\text { Analysis of Institutional Lock-In }\end{array}$ & $\begin{array}{l}\text { John S. Earle and Klara Z. } \\
\text { Sabirianova }\end{array}$ & Oct. 2000 \\
\hline No. 320 Rethinking Marketing Programs for Emerging Markets & $\begin{array}{l}\text { Niraj Dawar and Amitava } \\
\text { Chattopadhyay }\end{array}$ & June 2000 \\
\hline $\begin{array}{l}\text { No. } 319 \text { Public Finance and Low Equilibria in Transition Economies: } \\
\text { the Role of Institutions }\end{array}$ & $\begin{array}{l}\text { Daniel Daianu and Radu } \\
\text { Vranceanu }\end{array}$ & June 2000 \\
\hline $\begin{array}{l}\text { No. } 318 \text { Some Econometric Evidence on the Effectiveness of Active } \\
\text { Labour Market Programmes in East Germany }\end{array}$ & $\begin{array}{l}\text { Martin Eichler and Michael } \\
\text { Lechner }\end{array}$ & June 2000 \\
\hline No. 317 A Model of Russia’s "Virtual Economy" & R.E Ericson and B.W Ickes & May 2000 \\
\hline $\begin{array}{l}\text { No. } 316 \text { Financial Institutions, Financial Contagion, and Financial } \\
\text { Crises }\end{array}$ & $\begin{array}{l}\text { Haizhou Huang and Chenggang } \\
\mathrm{Xu}\end{array}$ & Mar. 2000 \\
\hline $\begin{array}{l}\text { No. } 315 \text { Privatization versus Regulation in Developing Economies: The } \\
\text { Case of West African Banks }\end{array}$ & $\begin{array}{l}\text { Jean Paul Azam, Bruno Biais, and } \\
\text { Magueye Dia }\end{array}$ & Feb. 2000 \\
\hline $\begin{array}{l}\text { No. } 314 \text { Is Life More Risky in the Open? Household Risk-Coping and } \\
\text { the Opening of China's Labor Markets }\end{array}$ & John Giles & Apr. 2000 \\
\hline $\begin{array}{l}\text { No. } 313 \text { Networks, Migration and Investment: Insiders and Outsiders in } \\
\text { Tirupur's Production Cluster }\end{array}$ & $\begin{array}{l}\text { Abhijit Banerjee and Kaivan } \\
\text { Munshi }\end{array}$ & Mar. 2000 \\
\hline $\begin{array}{l}\text { No. } 312 \text { Computational Analysis of the Impact on India of the Uruguay } \\
\text { Round and the Forthcoming WTO Trade Negotiations }\end{array}$ & $\begin{array}{l}\text { Rajesh Chadha, Drusilla K. } \\
\text { Brown, Alan V. Deardorff and } \\
\text { Robert M. Stern }\end{array}$ & Mar. 2000 \\
\hline No. 311 Subsidized Jobs for Unemployed Workers in Slovakia & Jan. C. van Ours & May 2000 \\
\hline No. 310 Determinants of Managerial Pay in the Czech Republic & $\begin{array}{l}\text { Tor Eriksson, Jaromir Gottvald } \\
\text { and Pavel Mrazek }\end{array}$ & May 2000 \\
\hline $\begin{array}{l}\text { No. } 309 \text { The Great Human Capital Reallocation: An Empirical Analysis } \\
\text { of Occupational Mobility in Transitional Russia }\end{array}$ & Klara Z. Sabirianova & Oct. 2000 \\
\hline No. 308 Economic Development, Legality, and the Transplant Effect & $\begin{array}{l}\text { Daniel Berkowitz, Katharina } \\
\text { Pistor, and Jean-Francois Richard }\end{array}$ & Feb. 2000 \\
\hline $\begin{array}{l}\text { No. } 307 \text { Community Participation, Teacher Effort, and Educational } \\
\text { Outcome: The Case of El Salvador's EDUCO Program }\end{array}$ & Yasuyuki Sawada & Nov. 1999 \\
\hline No. 306 Gender Wage Gap and Segregation in Late Transition & Stepan Jurajda & May 2000 \\
\hline $\begin{array}{l}\text { No. } 305 \text { The Gender Pay Gap in the Transition from Communism: } \\
\text { Some Empirical Evidence }\end{array}$ & Andrew Newell and Barry Reilly & May 2000 \\
\hline No. 304 Post-Unification Wage Growth in East Germany & Jennifer Hunt & Nov. 1998 \\
\hline $\begin{array}{l}\text { No. } 303 \text { How Does Privatization Affect Workers? The Case of the } \\
\text { Russian Mass Privatization Program }\end{array}$ & Elizabeth Brainerd & May 2000 \\
\hline $\begin{array}{l}\text { No. } 302 \text { Liability for Past Environmental Contamination and } \\
\text { Privatization }\end{array}$ & Dietrich Earnhart & Mar. 2000 \\
\hline No. 301 Varieties, Jobs and EU Enlargement & $\begin{array}{l}\text { Tito Boeri and Joaquim Oliveira } \\
\text { Martins }\end{array}$ & May 2000 \\
\hline No. 300 Employer Size Effects in Russia & Todd Idson & Apr. 2000 \\
\hline $\begin{array}{l}\text { No. } 299 \text { Information Complements, Substitutes, and Strategic Product } \\
\text { Design }\end{array}$ & $\begin{array}{l}\text { Geoffrey G. Parker and Marshall } \\
\text { W. Van Alstyne }\end{array}$ & Mar. 2000 \\
\hline $\begin{array}{l}\text { No. } 298 \text { Markets, Human Capital, and Inequality: Evidence from Rural } \\
\text { China }\end{array}$ & $\begin{array}{l}\text { Dwayne Benjamin, Loren Brandt, } \\
\text { Paul Glewwe, and Li Guo }\end{array}$ & May 2000 \\
\hline No. 297 Corporate Governance in the Asian Financial Crisis & $\begin{array}{l}\text { Simon Johnson, Peter Boone, } \\
\text { Alasdair Breach, and Eric } \\
\text { Friedman }\end{array}$ & Nov. 1999 \\
\hline No. 296 Competition and Firm Performance: Lesso & J. David Brown and John S. Earle & Mar. 2000 \\
\hline
\end{tabular}


Davidson Institute Working Papers are available at: www.wdi.bus.umich.edu

\begin{tabular}{|c|c|c|}
\hline No. 295 Wage Determination in Russia: An Econometric Investigation & $\begin{array}{l}\text { Peter J. Luke and Mark E. } \\
\text { Schaffer }\end{array}$ & Mar. 2000 \\
\hline $\begin{array}{l}\text { No. 294: Can Banks Promote Enterprise Restructuring?: Evidence From } \\
\text { a Polish Bank's Experience }\end{array}$ & John P. Bonin and Bozena Leven & Mar. 2000 \\
\hline No. 293: Why do Governments Sell Privatised Companies Abroad? & $\begin{array}{l}\text { Bernardo Bortolotti, Marcella } \\
\text { Fantini and Carlo Scarpa }\end{array}$ & Mar. 2000 \\
\hline $\begin{array}{l}\text { No. 292: Going Public in Poland: Case-by-Case Privatizations, Mass } \\
\text { Privatization and Private Sector Initial Public Offerings }\end{array}$ & Wolfgang Aussenegg & Dec. 1999 \\
\hline $\begin{array}{l}\text { No. 291: Institutional Technology and the Chains of Trust: Capital } \\
\text { Markets and Privatization in Russia and the Czech Republic }\end{array}$ & Bruce Kogut and Andrew Spicer & Mar. 1999 \\
\hline No. 290: Banking Crises and Bank Rescues: The Effect of Reputation & Jenny Corbett and Janet Mitchell & Jan. 2000 \\
\hline $\begin{array}{l}\text { No. 289: Do Active Labor Market Policies Help Unemployed Workers } \\
\text { to Find and Keep Regular Jobs? }\end{array}$ & Jan C. van Ours & Feb. 2000 \\
\hline No. 288: Consumption Patterns of the New Elite in Zimbabwe & ll Belk & Feb. 2000 \\
\hline $\begin{array}{l}\text { No. 287: Barter in Transition Economies: Competing Explanations } \\
\text { Confront Ukranian Data }\end{array}$ & $\begin{array}{l}\text { Dalia Marin, Daniel Kaufmann } \\
\text { and Bogdan Gorochowskij }\end{array}$ & Jan. 2000 \\
\hline $\begin{array}{l}\text { No. 286: The Quest for Pension Reform: Poland's Security through } \\
\text { Diversity }\end{array}$ & $\begin{array}{l}\text { Marek Góra and Michael } \\
\text { Rutkowski }\end{array}$ & Jan. 2000 \\
\hline No. 285: Disorganization and Financial Collapse & $\begin{array}{l}\text { Dalia Marin and Monika } \\
\text { Schnitzer }\end{array}$ & Oct. 1999 \\
\hline No. 284: Coordinating Changes in M-form and U-form Organizations & $\begin{array}{l}\text { Yingyi Qian, Gérard Roland and } \\
\text { Chenggang Xu }\end{array}$ & May 1999 \\
\hline $\begin{array}{l}\text { No. 283: Why Russian Workers Do Not Move: Attachment of Workers } \\
\text { Through In-Kind Payments }\end{array}$ & Guido Friebel and Sergei Guriev & Oct. 1999 \\
\hline No. 282: Lessons From Fiascos in Russian Corporate Governance & $\begin{array}{l}\text { Merritt B. Fox and Michael A. } \\
\text { Heller }\end{array}$ & Oct. 1999 \\
\hline $\begin{array}{l}\text { e Controls: Targeting a Social } \\
\mathrm{n}\end{array}$ & $\begin{array}{l}\text { Michael Alexeev and James } \\
\text { Leitzel }\end{array}$ & Mar. 1999 \\
\hline $\begin{array}{l}\text { No. 280: Starting Positions, Reform Speed, and Economic Outcomes in } \\
\text { Transitioning Economies }\end{array}$ & William Hallagan and Zhang Jun & Jan. 2000 \\
\hline No. 279 : The Value of Prominent Directors & $\begin{array}{l}\text { iro Miwa \& J. } \\
\text { eyer }\end{array}$ & Oct. 1999 \\
\hline No. 278: $\mathrm{Tl}$ & & Apr. 1998 \\
\hline $\begin{array}{l}\text { No. 277: The Developmental Consequences of Foreign Direct } \\
\text { Investment in the Transition from Socialism to Capitalism: The } \\
\text { Performance of Foreign Owned Firms in Hungary }\end{array}$ & Lawrence Peter King & Sept. 1999 \\
\hline $\begin{array}{l}\text { No. 276: Stability and Disorder: An Evolutionary Analysis of Russia's } \\
\text { Virtual Economy }\end{array}$ & $\begin{array}{l}\text { Clifford Gaddy and Barry W. } \\
\text { Ickes }\end{array}$ & Nov. 1999 \\
\hline $\begin{array}{l}\text { No. 275: Limiting Government Predation Through Anonymous } \\
\text { Banking: A Theory with Evidence from China. }\end{array}$ & $\begin{array}{l}\text { Chong-En Bai, David D. Li, } \\
\text { Yingyi Qian and Yijiang Wang }\end{array}$ & July 1999 \\
\hline No. 274: Transition with Labour Supply & Tito Boeri & Dec. 1999 \\
\hline $\begin{array}{l}\text { No. 273: Sectoral Restructuring and Labor Mobility: A Comparative } \\
\text { Look at the Czech Republic }\end{array}$ & Vit Sorm and Katherine Terrell & Nov. 1999 \\
\hline $\begin{array}{l}\text { No. 272: Published in: Journal of Comparative Economics "Returns to } \\
\text { Human Capital Under the Communist Wage Grid and During the } \\
\text { Transition to a Market Economy" Vol. 27, pp. 33-60 } 1999 .\end{array}$ & $\begin{array}{l}\text { Daniel Munich, Jan Svejnar and } \\
\text { Katherine Terrell }\end{array}$ & Oct. 1999 \\
\hline $\begin{array}{l}\text { No. 271: Barter in Russia: Liquidity Shortage Versus Lack of } \\
\text { Restructuring }\end{array}$ & $\begin{array}{l}\text { Sophie Brana and Mathilde } \\
\text { Maurel }\end{array}$ & June 1999 \\
\hline $\begin{array}{l}\text { No. 270: Tests for Efficient Financial Intermediation with Application to } \\
\text { China }\end{array}$ & Albert Park and Kaja Sehrt & Mar. 1999 \\
\hline $\begin{array}{l}\text { No. 269a: Russian Privatization and Corporate Governance: What Went } \\
\text { Wrong? }\end{array}$ & $\begin{array}{l}\text { Bernard Black, Reinier Kraakman } \\
\text { and Anna Tarassova }\end{array}$ & May 2000 \\
\hline $\begin{array}{l}\text { No. 269: Russian Privatization and Corporate Governance: What Went } \\
\text { Wrong? }\end{array}$ & $\begin{array}{l}\text { Bernard Black, Reinier Kraakman } \\
\text { and Anna Tarassova }\end{array}$ & Sept. 1999 \\
\hline No. 268: Are Russians Really Ready for Capitalism? & Susan Linz & Sept. 1999 \\
\hline
\end{tabular}


Davidson Institute Working Papers are available at: www.wdi.bus.umich.edu

\begin{tabular}{|c|c|c|}
\hline No. 267: Do Stock Markets Promote Economic Growth? & $\begin{array}{l}\text { Randall K. Filer, Jan Hanousek } \\
\text { and Nauro Campos }\end{array}$ & Sept. 1999 \\
\hline $\begin{array}{l}\text { No. 266: Objectivity, Proximity and Adaptability in Corporate } \\
\text { Governance }\end{array}$ & $\begin{array}{l}\text { Arnoud W.A Boot and Jonathan } \\
\text { R. Macey }\end{array}$ & Sept. 1999 \\
\hline $\begin{array}{l}\text { No. 265: When the Future is not What it Used to Be: Lessons from the } \\
\text { Western European Experience to Forecasting Education and Training in } \\
\text { Transitional Economies }\end{array}$ & $\begin{array}{l}\text { Nauro F. Campos, Gerard } \\
\text { Hughes, Stepan Jurajda, and } \\
\text { Daniel Munich }\end{array}$ & Sept. 1999 \\
\hline $\begin{array}{l}\text { No. 264: The Institutional Foundation of Foreign-Invested Enterprises } \\
\text { (FIEs) in China }\end{array}$ & Yasheng Huang & Sept. 1999 \\
\hline $\begin{array}{l}\text { No. 263: The Changing Corporate Governance Paradigm: Implications } \\
\text { for Transition and Developing Countries }\end{array}$ & $\begin{array}{l}\text { Erik Berglof and Ernst-Ludwig } \\
\text { von Thadden }\end{array}$ & June 1999 \\
\hline No. 262: Law Enforcement and Transition & $\begin{array}{l}\text { Gerard Roland and Thierry } \\
\text { Verdier }\end{array}$ & May 1999 \\
\hline $\begin{array}{l}\text { No. 261: Soft Budget Constraints, Pecuniary Externality, and the Dual } \\
\text { Track System }\end{array}$ & Jiahua Che & June 2000 \\
\hline $\begin{array}{l}\text { No. 260: Missing Market in Labor Quality: The Role of Quality Markets } \\
\text { in Transition }\end{array}$ & Gary H. Jefferson & July 1999 \\
\hline $\begin{array}{l}\text { No. 259: Do Corporate Global Environmental Standards in Emerging } \\
\text { Markets Create or Destroy Market Value }\end{array}$ & $\begin{array}{l}\text { Glen Dowell, Stuart H } \\
\text { Bernard Yeung }\end{array}$ & June 1999 \\
\hline No. 258: Public Training and Outflows from Unemployment & Patrick A. Puhani & June 1999 \\
\hline $\begin{array}{l}\text { No. 257: Ownership Versus Environment: Why are Public Sector Firms } \\
\text { Inefficient? }\end{array}$ & $\begin{array}{l}\text { Bartel and Ann E. } \\
\text { on }\end{array}$ & June 1999 \\
\hline $\begin{array}{l}\text { No. 256: Taxation and Evasion in the Presence of Exortion by } \\
\text { Organized Crime }\end{array}$ & Eckhard Janeba & Nov. 1999 \\
\hline No. 255: Revisiting Hungary's Bankruptcy Episode & $\begin{array}{l}\text { John P. Bonin } \\
\text { Schaffer }\end{array}$ & Sept. 1999 \\
\hline No. 254: FDI in & v.N Whitman & 1999 \\
\hline $\begin{array}{l}\text { No. 253: The Asian Financial Crisis: What Happened, and What is to be } \\
\text { Done }\end{array}$ & $\begin{array}{l}\text { Jeffrey D. Sachs and W } \\
\text { Woo }\end{array}$ & Jan. 1999 \\
\hline No. 252: Organizational Law as Asset Partitioning & $\begin{array}{l}\mathrm{He} \\
\mathrm{Kr}\end{array}$ & Sept. 1999 \\
\hline $\begin{array}{l}\text { No. } 251: \text { Consur } \\
\text { the Case of the }(\end{array}$ & enkamp & Sept. 1999 \\
\hline $\begin{array}{l}\text { Rights Formation and the Organization of Exchange } \\
\text { Rural China }\end{array}$ & $\begin{array}{l}\text { ren } \\
\text { lle }\end{array}$ & July 1998 \\
\hline $\begin{array}{l}\text { No. 249: Impacts of the Indonesian Economic Crisis: Price Changes and } \\
\text { the Poor }\end{array}$ & en Berry, & June 1999 \\
\hline $\begin{array}{l}\text { No. 248: Internal Barriers in the Transition of Enterprises from Central } \\
\text { Plan to Market }\end{array}$ & Charalambos Vlachoutsicos & July 1999 \\
\hline $\begin{array}{l}\text { No. 247: Spillovers from Multinationals in Developing Countries: the } \\
\text { Mechanisms at Work }\end{array}$ & Richard E. Caves & June 1999 \\
\hline $\begin{array}{l}\text { No. 246: Dynamism and Inertia on the Russian Labour Market: A } \\
\text { Model of Segmentation }\end{array}$ & $\begin{array}{l}\text { Irena Grosfeld, Claudia Senik- } \\
\text { Leygonie, Thierry Verdier, Stanislav } \\
\text { Kolenikov and Elena Paltseva }\end{array}$ & May 1999 \\
\hline No. 245: L & John Bonin and Paul Wachtel & May 1999 \\
\hline $\begin{array}{l}\text { No. 244: Nominal-Real Tradeoffs and the Effects of Monetary Policy: } \\
\text { the Romanian Experience }\end{array}$ & Christian Popa & Dec. 1998 \\
\hline $\begin{array}{l}\text { No. 243: Privatization, Political Risk and Stock Market Development in } \\
\text { Emerging Economies }\end{array}$ & $\begin{array}{l}\text { Enrico C. Perotti and Pieter van } \\
\text { Oijen }\end{array}$ & Mar. 1999 \\
\hline No. 242: Investment Financing in Russian Financial-Industrial Groups & $\begin{array}{l}\text { Enrico C. Perotti and Stanislav } \\
\text { Gelfer }\end{array}$ & Oct. 1998 \\
\hline $\begin{array}{l}\text { No. 241: Can governments maintain hard budget constraints? Bank } \\
\text { lending and financial isolation in Romania }\end{array}$ & $\begin{array}{l}\text { Octavian Carare, Constantijn } \\
\text { Claessens, Enrico C. Perotti }\end{array}$ & Jan. 1999 \\
\hline $\begin{array}{l}\text { No. 240: Democratic Institutions and Economic Reform: the Polish } \\
\text { Case }\end{array}$ & $\begin{array}{l}\text { John E. Jackson, Jacek Klich, and } \\
\text { Krystyna Poznanska }\end{array}$ & Apr. 1998 \\
\hline
\end{tabular}




\begin{tabular}{|c|c|c|}
\hline No. 239: A Longitudinal Study of IJV Performance in Eastern Europe & $\begin{array}{l}\text { Keith D. Brouthers and Gary } \\
\text { Bamossy }\end{array}$ & June 1999 \\
\hline $\begin{array}{l}\text { No. 238: Published in: Journal of Business Venturing, "Firm Creation } \\
\text { and Economic Transitions" } 14(5,6) \text { Sep/Nov 1999, pp. 427-450. }\end{array}$ & $\begin{array}{l}\text { John E. Jackson, Jacek Klich, } \\
\text { Krystyna Poznanska }\end{array}$ & July 1998 \\
\hline No. 237: Analysis of Entrepreneurial Attitudes in Poland & $\begin{array}{l}\text { John E. Jackson and Aleksander } \\
\text { S. Marcinkowski }\end{array}$ & Mar. 1997 \\
\hline $\begin{array}{l}\text { No. 236: Investment and Finance in De Novo Private Firms: Empirical } \\
\text { Results from the Czech Republic, Hungary, and Poland }\end{array}$ & $\begin{array}{l}\text { Andrzej Bratkowski, Irena } \\
\text { Grosfeld, Jacek Rostowski }\end{array}$ & Apr. 1999 \\
\hline $\begin{array}{l}\text { No. 235: Does a Soft Macroeconomic Environment Induce } \\
\text { Restructuring on the Microeconomic Level during the Transition } \\
\text { Period? Evidence from Investment Behavior of Czech Enterprises }\end{array}$ & Lubomír Lízal & June 1999 \\
\hline $\begin{array}{l}\text { No. 234: Banking Reform in China: Gradually Strengthening Pillar or } \\
\text { Fragile Reed? }\end{array}$ & John Bonin & June 1999 \\
\hline $\begin{array}{l}\text { No. 233: Theories of Soft Budget Constraints and the Analysis of } \\
\text { Banking Crises }\end{array}$ & Janet Mitchell & Mar. 1999 \\
\hline $\begin{array}{l}\text { No. 232: Unemployment Risk, Precautionary Savings, and } \\
\text { Moonlighting in Russia }\end{array}$ & $\begin{array}{l}\text { Alessandra Guariglia and Byung- } \\
\text { Yeon Kim }\end{array}$ & June 1999 \\
\hline $\begin{array}{l}\text { No. 231: Investing in Turbulent Times: The Investment Behavior of } \\
\text { Polish Firms in the Transition }\end{array}$ & $\begin{array}{l}\text { Josef C. Brada, Arthur E. King, } \\
\text { and Chia-Ying Ma }\end{array}$ & Apr. 1999 \\
\hline No. 230: The End of Moderate Inflation in Three Transition Economies? & Josef C. Brada and Ali M. Kutan & Apr. 1999 \\
\hline $\begin{array}{l}\text { No. 229: Back to the Future: The Growth Prospects of Transition } \\
\text { Economies Reconsidered }\end{array}$ & Nauro F. Campos & Apr. 1999 \\
\hline No. 228: The Enterprise Isolation Program in Russia & Simeon Djankov & Apr. 1999 \\
\hline $\begin{array}{l}\text { No. 227: Published in: Journal of Comparative Economics, "Ownership } \\
\text { Concentration and Corporate Performance in the Czech Republic" } \\
\text { 27(3), Sept. 1999, pp. 498-513. }\end{array}$ & $\begin{array}{l}\text { Stijn Claessens and Simeon } \\
\text { Djankov }\end{array}$ & Apr. 1999 \\
\hline $\begin{array}{l}\text { No. 226: Published in Journal of Population Economics, "Poland on the } \\
\text { Dole: The Effect of Reducing the Unemployment Benefit Entitlement } \\
\text { Period during Transition" 13:35-44, } 2000 \text {. }\end{array}$ & Patrick A. Puhani & Mar. 1999 \\
\hline No. 225: Transition at Whirlpool-Tatramat: Case Studies & $\begin{array}{l}\text { Hans Brechbuhl and Sonia } \\
\text { Ferencikova }\end{array}$ & Mar. 1999 \\
\hline $\begin{array}{l}\text { No. 224: Measuring Progress in Transition and Towards EU Accession: } \\
\text { A Comparison of Manufacturing Firms in Poland, Romania, and Spain }\end{array}$ & $\begin{array}{l}\text { Wendy Carlin, Saul Estrin, and } \\
\text { Mark Schaffer }\end{array}$ & Mar. 1999 \\
\hline $\begin{array}{l}\text { No. 223: Product Market Competition in Transition Economies: } \\
\text { Increasing Varieties and Consumer Loyalty }\end{array}$ & Mitsutoshi M. Adachi & Mar. 1999 \\
\hline $\begin{array}{l}\text { No. 222: Opaque Markets and Rapid Growth: the Superiority of Bank- } \\
\text { Centered Financial Systems for Developing Nations }\end{array}$ & Rodney Wallace & July 1999 \\
\hline No. 221: Technology Spillovers through Foreign Direct Investment & Yuko Kinoshita & Jan. 1999 \\
\hline $\begin{array}{l}\text { No. 220: Managerial, Expertise and Team Centered Forms of } \\
\text { Organizing: A Cross-Cultural Exploration of Independence in } \\
\text { Engineering Work }\end{array}$ & Leslie Perlow & Jan. 1999 \\
\hline $\begin{array}{l}\text { No. 219: Household Structure and Labor Demand in Agriculture: } \\
\text { Testing for Separability in Rural China }\end{array}$ & $\begin{array}{l}\text { Audra J. Bowlus and Terry } \\
\text { Sicular }\end{array}$ & Jan. 1999 \\
\hline $\begin{array}{l}\text { No. 218: Competing Strategies of FDI and Technology Transfer to } \\
\text { China: American and Japanese Firms }\end{array}$ & $\begin{array}{l}\text { W. Mark Fruin and Penelope } \\
\text { Prime }\end{array}$ & Jan. 1999 \\
\hline $\begin{array}{l}\text { No. } 217 \text { Published in: Journal of Comparative Economics, "Returns to } \\
\text { Mobility in the Transition to a Market Economy" 27(1), Mar } 1999 .\end{array}$ & $\begin{array}{l}\text { Tito Boeri and Christopher J. } \\
\text { Flinn }\end{array}$ & Jan. 1999 \\
\hline $\begin{array}{l}\text { No. } 216 \text { Published in: Journal of Comparative Economics, "Labor } \\
\text { Market Policies and Unemployment in the Czech Republic." 27(1), Mar } \\
\text { 1999, pp. 33-60. }\end{array}$ & Katherine Terrell and Vit Sorm & Nov. 1998 \\
\hline $\begin{array}{l}\text { No. } 215 \text { Published in: Journal of Comparative Economics, “Active } \\
\text { Labor Market Policies in Poland: Human Capital Enhancement, } \\
\text { Stigmatization or Benefit Churning?" 27(1), Mar 1999, pp. 61-. }\end{array}$ & $\begin{array}{l}\text { Jochen Kluve, Hartmut Lehmann, } \\
\text { and Christoph M. Schmidt }\end{array}$ & Dec. 1998 \\
\hline $\begin{array}{l}\text { No. } 214 \text { Published in: Journal of Comparative Economics, "Does the } \\
\text { Slovenian Public Work Program Increase Participants' Chances to Find } \\
\text { a Job?" 27(1), Mar 1999, pp. 113- . }\end{array}$ & Milan Vodopivec & Dec. 1998 \\
\hline
\end{tabular}




\begin{tabular}{|c|c|c|}
\hline $\begin{array}{l}\text { No. } 213 \text { Published in: Journal of Comparative Economics, "Effects of } \\
\text { Active Labor Market Programs on the Transition Rate from } \\
\text { Unemployment into Regular Jobs in the Slovak Republic." 27(1), Mar } \\
\text { 1999, pp. 90-. }\end{array}$ & $\begin{array}{l}\text { Martina Lubyova and Jan C. van } \\
\text { Ours }\end{array}$ & Dec. 1998 \\
\hline $\begin{array}{l}\text { No. 212: The Marketing System in Bulgarian Livestock Production - } \\
\text { The Present State and Evolutionary Processes During the Period of } \\
\text { Economic Transition }\end{array}$ & Yordan Staykov, Team Leader & Oct. 1998 \\
\hline No. 211: Bankruptcy Experience in Hungary and the Czech Republic & Janet Mitchell & Oct. 1998 \\
\hline $\begin{array}{l}\text { No 210: Values, Optimum Stimulation Levels and Brand Loyalty: New } \\
\text { Scales in New Populations }\end{array}$ & $\begin{array}{l}\text { Steven M. Burgess and Mari } \\
\text { Harris }\end{array}$ & Sept. 1998 \\
\hline No. 209: Inherited Wealth, Corporate Control and Economic Growth & $\begin{array}{l}\text { Randall K. Morck, David A. } \\
\text { Stangeland, and Bernard Yeung }\end{array}$ & Sept. 1998 \\
\hline $\begin{array}{l}\text { No. 208: A Cultural Analysis of Homosocial Reproduction and } \\
\text { Contesting Claims to Competence in Transitional Firms }\end{array}$ & Michael D. Kennedy & July 1998 \\
\hline $\begin{array}{l}\text { No. 207: From Survival to Success: The Journey of Corporate } \\
\text { Transformation at Haier. Forthcoming in Managing Organizational } \\
\text { Change in Transition Economies ed. Daniel Denison. }\end{array}$ & $\begin{array}{l}\text { Arthur Yeung and Kenneth } \\
\text { DeWoskin }\end{array}$ & July 1998 \\
\hline $\begin{array}{l}\text { No. 206: Why Do People Work If They Are Not Paid? An Example } \\
\text { from Eastern Europe. Forthcoming in Managing Organizational Change } \\
\text { in Transition Economies. }\end{array}$ & Irina L. Zinovieva & May 1998 \\
\hline $\begin{array}{l}\text { No. 205: Firm Ownership and Work Motivation in Bulgaria and } \\
\text { Hungary: An Empirical Study of the Transition in the Mid-1990s. } \\
\text { Forthcoming in Managing Organizational Change in Transition } \\
\text { Economies ed. Daniel Denison. }\end{array}$ & $\begin{array}{l}\text { Robert A. Roe, Irina L. } \\
\text { Zinovieva, Elizabeth Dienes, and } \\
\text { Laurens A. ten Horn }\end{array}$ & May 1998 \\
\hline $\begin{array}{l}\text { No. 204: Human Resource Management in the Restructuring of Chinese } \\
\text { Joint Ventures. Forthcoming in Managing Organizational Change in } \\
\text { Transition Economies ed. Daniel Denison. }\end{array}$ & Nandani Lynton & Apr. 1998 \\
\hline $\begin{array}{l}\text { No. 203: Emergent Compensation Strategies in Post-Socialist Poland: } \\
\text { Understanding the Cognitive Underpinnings of Management Practices } \\
\text { in a Transition Economy. Forthcoming in Managing Organizational } \\
\text { Change in Transition Economies ed. Daniel Denison. }\end{array}$ & Marc Weinstein & Mar. 1998 \\
\hline $\begin{array}{l}\text { No. 202: Corporate Transformation and Organizational Learning: The } \\
\text { People's Republic of China. Forthcoming in Managing Organizational } \\
\text { Change in Transition Economies ed. Daniel Denison. }\end{array}$ & $\begin{array}{l}\text { Meinolf Dierkes and Zhang } \\
\text { Xinhua }\end{array}$ & Mar. 1998 \\
\hline $\begin{array}{l}\text { No. 201: Foreign Direct Investment as a Factor of Change: The Case of } \\
\text { Slovakia. Forthcoming in Managing Organizational Change in } \\
\text { Transition Economies ed. Daniel Denison. }\end{array}$ & Sonia Ferencikova & Feb. 1998 \\
\hline $\begin{array}{l}\text { No. 200: Radical versus Incremental Change: The Role of Capabilities, } \\
\text { Competition, and Leaders. Forthcoming in Managing Organizational } \\
\text { Change in Transition Economies ed. Daniel Denison. }\end{array}$ & Karen L. Newman & Feb. 1998 \\
\hline $\begin{array}{l}\text { No. 199: The Emergence of Market Practices in China's Economic } \\
\text { Transition: Price Setting Practices in Shanghai's Industrial Firms. } \\
\text { Forthcoming in Managing Organizational Change in Transition } \\
\text { Economies ed. Daniel Denison. }\end{array}$ & Douglas Guthrie & Feb. 1998 \\
\hline $\begin{array}{l}\text { No. 198: The Application of Change Management Methods at Business } \\
\text { Organizations Operating in Hungary: Challenges in the Business and } \\
\text { Cultural Environment and First Practical Experiences. Forthcoming in } \\
\text { Managing Organizational Change in Transition Economies ed. Daniel } \\
\text { Denison. }\end{array}$ & Dr. János Fehér & Jan. 1998 \\
\hline $\begin{array}{l}\text { No. 197: Organizational Changes in Russian Industrial Enterprises: } \\
\text { Mutation of Decision-Making Structures and Transformations of } \\
\text { Ownership. Forthcoming in Managing Organizational Change in } \\
\text { Transition Economies ed. Daniel Denison. }\end{array}$ & Igor B. Gurkov & Jan. 1998 \\
\hline $\begin{array}{l}\text { No. 196: Understanding and Managing Challenges to the Romanian } \\
\text { Companies during Transition. Forthcoming in Managing Organizational } \\
\text { Change in Transition Economies ed. Daniel Denison. }\end{array}$ & $\begin{array}{l}\text { Dan Candea and Rodica M. } \\
\text { Candea }\end{array}$ & Jan. 1998 \\
\hline
\end{tabular}




\begin{tabular}{|c|c|c|}
\hline $\begin{array}{l}\text { No. 195: Insider Lending and Economic Transition: The Structure, } \\
\text { Function, and Performance Impact of Finance Companies in Chinese } \\
\text { Business Groups. Forthcoming in Managing Organizational Change in } \\
\text { Transition Economies ed. Daniel Denison. }\end{array}$ & Lisa A. Keister & Dec. 1997 \\
\hline $\begin{array}{l}\text { No. 194: Japanese Investment in Transitional Economies: } \\
\text { Characteristics and Performance. Forthcoming in Managing } \\
\text { Organizational Change in Transition Economies ed. Daniel Denison. }\end{array}$ & $\begin{array}{l}\text { Paul W. Beamish and Andrew } \\
\text { Delios }\end{array}$ & Nov. 1997 \\
\hline $\begin{array}{l}\text { No. 193: Building Successful Companies in Transition Economies. } \\
\text { Forthcoming in Managing Organizational Change in Transition } \\
\text { Economies ed. Daniel Denison. }\end{array}$ & Dr. Ivan Perlaki & Jan. 1998 \\
\hline $\begin{array}{l}\text { No. 192: Russian Communitariansim: An Invisible Fist in the } \\
\text { Transformation Process of Russia. Forthcoming in Managing } \\
\text { Organizational Change in Transition Economies ed. Daniel Denison. }\end{array}$ & Charalambos Vlachoutsicos & July 1998 \\
\hline No. 191: Teaching the Dinosaurs to Dance & Michal Cakrt & Sept. 1997 \\
\hline $\begin{array}{l}\text { No. 190: Strategic Restructuring: Making Capitalism in Post- } \\
\text { Communist Eastern Europe. Forthcoming in Managing Organizational } \\
\text { Change in Transition Economies ed. Daniel Denison. }\end{array}$ & Lawrence P. King & Sept. 1997 \\
\hline $\begin{array}{l}\text { No. 189: Published in: Regional Science and Urban Economics, } \\
\text { "Russia's Internal Border." 29(5), Sept. } 1999 .\end{array}$ & $\begin{array}{l}\text { Daniel Berkowitz and David N. } \\
\text { DeJong }\end{array}$ & July 1998 \\
\hline No. 187: Corporate Structure and Performance in Hungary & László Halpern and Gábor Kórsöi & July 1998 \\
\hline No. 186: Performance of Czech Companies by Ownership Structure & $\begin{array}{l}\text { Andrew Weiss and Georgiy } \\
\text { Nikitin }\end{array}$ & June 1998 \\
\hline $\begin{array}{l}\text { No. 185: Firm Performance in Bulgaria and Estonia: The effects of } \\
\text { competitive pressure, financial pressure and disorganisation }\end{array}$ & Jozef Konings & July 1998 \\
\hline $\begin{array}{l}\text { No. 184: Investment and Wages during the Transition: Evidence from } \\
\text { Slovene Firms }\end{array}$ & Janez Prasnikar and Jan Svejnar & July 1998 \\
\hline $\begin{array}{l}\text { No. 183: Investment Portfolio under Soft Budget: Implications for } \\
\text { Growth, Volatility and Savings }\end{array}$ & Chongen Bai and Yijiang Wang & July 1998 \\
\hline No. 181: Delegation and Delay in Bank Privatization & $\begin{array}{l}\text { Loránd Ambrus-Lakatos and } \\
\text { Ulrich Hege }\end{array}$ & July 1998 \\
\hline No. 180: Financing Mechanisms and R\&D Investment & $\begin{array}{l}\text { Haizhou Huang and Chenggang } \\
\mathrm{Xu}\end{array}$ & July 1998 \\
\hline $\begin{array}{l}\text { No. 179: Organizational Culture and Effectiveness: The Case of Foreign } \\
\text { Firms in Russia }\end{array}$ & $\begin{array}{l}\text { Carl F. Fey and Daniel R. } \\
\text { Denison }\end{array}$ & Jan. 1999 \\
\hline No. 178: Output and Unemployment Dynamics in Transition & $\begin{array}{l}\text { Vivek H. Dehejia and Douglas W. } \\
\text { Dwyer }\end{array}$ & Jan. 1998 \\
\hline $\begin{array}{l}\text { No. 177: Published in: Economics of Transition, "Bureaucracies in the } \\
\text { Russian Voucher Privatization." } 8(1), 2000, \text { pp. } 37-57 .\end{array}$ & Guido Friebel & June 1998 \\
\hline No. 176: Chronic Moderate Inflation in Transition: The Tale of Hungary & János Vincze & June 1998 \\
\hline No. 175: Privatisation and Market Structure in a Transition Economy & John Bennett and James Maw & June 1998 \\
\hline $\begin{array}{l}\text { No. 174: Ownership and Managerial Competition: Employee, Customer, } \\
\text { or Outside Ownership }\end{array}$ & $\begin{array}{l}\text { Patrick Bolton and Chenggang } \\
\mathrm{Xu}\end{array}$ & June 1998 \\
\hline $\begin{array}{l}\text { No. 173: Intragovernment Procurement of Local Public Good: A } \\
\text { Theory of Decentralization in Nondemocratic Government }\end{array}$ & $\begin{array}{l}\text { Chong-en Bai, Yu Pan and } \\
\text { Yijiang Wang }\end{array}$ & June 1998 \\
\hline No. 172: Political Instability and Growth in Proprietary Economies & $\begin{array}{l}\text { Jody Overland and Michael } \\
\text { Spagat }\end{array}$ & Aug. 1998 \\
\hline $\begin{array}{l}\text { No. 171: Published in Post-Communist Economies, "Framework Issues } \\
\text { in the Privatization Strategies of the Czech Republic, Hungary, and } \\
\text { Poland" 11(1) Mar. } 1999 .\end{array}$ & Morris Bornstein & June 1998 \\
\hline $\begin{array}{l}\text { No. 170: Published in: European Journal of Political Economy } \\
\text { "Privatization, Ownership Structure and Transparency: How to Measure } \\
\text { a Real Involvement of the State" 15(4), Nov. 1999, pp. 605-18. }\end{array}$ & Frantisek Turnovec & May 1998 \\
\hline $\begin{array}{l}\text { No. } 169 \text { Published in: American Economic Review, "Unemployment and } \\
\text { the Social Safety Net during Transitions to a Market Economy: } \\
\text { Evidence from Czech and Slovak Men" 88(5), Dec 1998, pp. 1117-1142 }\end{array}$ & $\begin{array}{l}\text { John C. Ham, Jan Svejnar, and } \\
\text { Katherine Terrell }\end{array}$ & Dec. 1998 \\
\hline
\end{tabular}




\begin{tabular}{|c|c|c|}
\hline $\begin{array}{l}\text { No. 167: Voucher Privatization with Investment Funds: An Institutional } \\
\text { Analysis }\end{array}$ & David Ellerman & Mar. 1998 \\
\hline $\begin{array}{l}\text { No. 166: Published in: Marketing Issues in Transitional Economies, } \\
\text { "Value Priorities and Consumer Behavior in a Transitional Economy: } \\
\text { The Case of South Africa" ed. Rajeev Batra. }\end{array}$ & $\begin{array}{l}\text { Steven M. Burgess and Jan- } \\
\text { Benedict E.M. Steenkamp }\end{array}$ & Aug. 1998 \\
\hline $\begin{array}{l}\text { No. 164: Finance and Investment in Transition: Czech Enterprises, } \\
\text { 1993-1994 }\end{array}$ & $\begin{array}{l}\text { Ronald Anderson and Chantal } \\
\text { Kegels }\end{array}$ & Sept. 1997 \\
\hline $\begin{array}{l}\text { No. 163: European Union Trade and Investment Flows U-Shaping } \\
\text { Industrial Output in Central and Eastern Europe: Theory and Evidence }\end{array}$ & $\begin{array}{l}\text { Alexander Repkine and Patrick P. } \\
\text { Walsh }\end{array}$ & Apr. 1998 \\
\hline $\begin{array}{l}\text { No. 162: Skill Acquisition and Private Firm Creation in Transition } \\
\text { Economies }\end{array}$ & Zuzana Brixiova and Wenli Li & Oct. 1999 \\
\hline No. 161: Corruption in Transition & Susanto Basu and David D. Li & May 1998 \\
\hline $\begin{array}{l}\text { No. 160a: Tenures that Shook the World: Worker Turnover in Russia, } \\
\text { Poland and Britain }\end{array}$ & $\begin{array}{l}\text { Hartmut Lehmann and Jonathan } \\
\text { Wadsworth }\end{array}$ & Nov. 1999 \\
\hline $\begin{array}{l}\text { No. 160: Tenures that Shook the World: Worker Turnover in the } \\
\text { Russian Federation and Poland }\end{array}$ & $\begin{array}{l}\text { Hartmut Lehmann and Jonathan } \\
\text { Wadsworth }\end{array}$ & June 1998 \\
\hline No. 159: Does Market Structure Matter? New Evidence from Russia & $\begin{array}{l}\text { Annette N. Brown and J. David } \\
\text { Brown }\end{array}$ & June 1998 \\
\hline $\begin{array}{l}\text { No. 158: Structural Adjustment and Regional Long Term } \\
\text { Unemployment in Poland }\end{array}$ & $\begin{array}{l}\text { Hartmut Lehmann and Patrick P. } \\
\text { Walsh }\end{array}$ & June 1997 \\
\hline $\begin{array}{l}\text { No. 157: Baby Boom or Bust? Changing Fertility in Post-Communist } \\
\text { Czech Republic and Slovakia }\end{array}$ & Robert S. Chase & Apr. 1998 \\
\hline $\begin{array}{l}\text { No. } 156 \text { Published in: Leadership and Organization Development } \\
\text { Journal, "Leading Radical Change in Transition Economies." Vol. 19, } \\
\text { No. 6, 1998, pp. 309-324. }\end{array}$ & Karen L. Newman & June 1998 \\
\hline $\begin{array}{l}\text { No. } 155 \text { Published in: Oxford Review of Economic Policy, "From } \\
\text { Theory into Practice? Restructuring and Dynamism in Transition } \\
\text { Economies." Vol. 13, No. 2, Summer 1997, pp. 77-105. }\end{array}$ & $\begin{array}{l}\text { Wendy Carlin and Michael } \\
\text { Landesmann }\end{array}$ & June 1997 \\
\hline $\begin{array}{l}\text { No. 154: The Model and the Reality: Assessment of Vietnamese SOE } \\
\text { Reform-Implementation at the Firm Level }\end{array}$ & $\begin{array}{l}\text { Edmund Malesky, Vu Thanh } \\
\text { Hung, Vu Thi Dieu Anh, and } \\
\text { Nancy K. Napier }\end{array}$ & July 1998 \\
\hline $\begin{array}{l}\text { No. } 153 \text { Published in: Journal of Comparative Economics, "Causes of } \\
\text { the Soft Budget Constraint: Evidence on Three Explanations." Vol. 26, } \\
\text { No. 1, Mar. 1998, pp. 104-116. }\end{array}$ & David D. Li and Minsong Liang & Mar. 1998 \\
\hline $\begin{array}{l}\text { No. } 152 \text { Published in: Comparative Economic Studies, "Enterprise } \\
\text { Restructuring in Russia's Transition Economy: Formal and Informal } \\
\text { Mechanisms." Vol. 40, No. 2, Summer 1998, pp. 5-52. }\end{array}$ & Susan J. Linz and Gary Krueger & Apr. 1998 \\
\hline $\begin{array}{l}\text { No. 151: Labor Productivity in Transition: A Regional Analysis of } \\
\text { Russian Industry }\end{array}$ & Susan J. Linz & May 1998 \\
\hline $\begin{array}{l}\text { No. 150: Tax Avoidance and the Allocation of Credit. Forthcoming in } \\
\text { Financial Systems in Transition: The Design of Financial Systems in } \\
\text { Central Europe eds. Anna Meyendorff and Anjan Thakor. }\end{array}$ & Anna Meyendorff & June 1998 \\
\hline $\begin{array}{l}\text { No. 149: Commitment, Versatility and Balance: Determinants of Work } \\
\text { Time Standards and Norms in a Multi-Country Study of Software } \\
\text { Engineers }\end{array}$ & Leslie Perlow and Ron Fortgang & Apr. 1998 \\
\hline $\begin{array}{l}\text { No. 148: Changes in Poland's Transfer Payments in the 1990s: the Fate } \\
\text { of Pensioners }\end{array}$ & Bozena Leven & June 1998 \\
\hline $\begin{array}{l}\text { No. 147: Environmental Protection and Economic Development: The } \\
\text { Case of the Huaihe River Basin Cleanup Plan }\end{array}$ & $\begin{array}{l}\text { Robert Letovsky, Reze Ramazani, } \\
\text { and Debra Murphy }\end{array}$ & June 1998 \\
\hline $\begin{array}{l}\text { No. 146: Chief Executive Compensation During Early Transition: } \\
\text { Further Evidence from Bulgaria }\end{array}$ & $\begin{array}{l}\text { Derek C. Jones, Takao Kato, and } \\
\text { Jeffrey Miller }\end{array}$ & June 1998 \\
\hline $\begin{array}{l}\text { No. } 145 \text { Published in: Economics of Transition, "Women's } \\
\text { Unemployment During the Transition: Evidence from Czech and Slovak } \\
\text { Micro Data," Vol. 7, No. 1, May 1999, pp. 47-78. }\end{array}$ & $\begin{array}{l}\text { John Ham, Jan Svejnar, and } \\
\text { Katherine Terrell }\end{array}$ & May 1998 \\
\hline No. 144: Investment and Wages in Slovenia & Janez Prasnikar & May 1998 \\
\hline
\end{tabular}


Davidson Institute Working Papers are available at: www.wdi.bus.umich.edu

\begin{tabular}{|c|c|c|}
\hline $\begin{array}{l}\text { No. } 143 \text { Published in: Review of Financial Studies, "Optimal } \\
\text { Bankruptcy Laws Across Different Economic Systems," 12(2), 47-77, } \\
\text { Summer 19993. }\end{array}$ & $\begin{array}{l}\text { Elazar Berkovitch and Ronen } \\
\text { Israel }\end{array}$ & Mar. 1998 \\
\hline $\begin{array}{l}\text { No. 142: Industrial Policy and Poverty in Transition Economies: Two } \\
\text { Steps Forward or One Step Back? }\end{array}$ & Susan J. Linz & Mar. 1998 \\
\hline $\begin{array}{l}\text { No. } 141 \text { Collective Ownership and Privatization of China's Village } \\
\text { Enterprises }\end{array}$ & Suwen Pan and Albert Park & Apr. 1998 \\
\hline $\begin{array}{l}\text { No. } 140 \text { A Comparative Look at Labor Mobility in the Czech Republic: } \\
\text { Where have all the Workers Gone? }\end{array}$ & Vit Sorm and Katherine Terrell & Apr. 1999 \\
\hline $\begin{array}{l}\text { No. } 139 \text { The Failure of the Government-Led Program of Corporate } \\
\text { Reorganization in Romania }\end{array}$ & $\begin{array}{l}\text { Simeon Djankov and Kosali } \\
\text { Ilayperuma }\end{array}$ & Sept. 1997 \\
\hline No. 138 Ownership and Employment in Russian Industry: 1992-1995 & Susan J. Linz & Mar. 1998 \\
\hline $\begin{array}{l}\text { No. } 137 \text { Published in: Journal of Political Economy, "Reform Without } \\
\text { Losers: An Interpretation of China's Dual-Track Approach to } \\
\text { Transition," Feb. 2000; Vol. 108, Iss.1; pg. } 120\end{array}$ & $\begin{array}{l}\text { Lawrence J. Lau, Yingyi Qian, } \\
\text { and Gerard Roland }\end{array}$ & Nov. 1997 \\
\hline $\begin{array}{l}\text { No. } 136 \text { Published in: European Economic Review, "The Political } \\
\text { Economy of Mass Privatization and the Risk of Expropriation," 44(2), } \\
\text { Feb. 2000, pgs. } 393-421\end{array}$ & Klaus M. Schmidt & Mar. 1998 \\
\hline $\begin{array}{l}\text { No. 135: Radical Organizational Change: The Role of Starting } \\
\text { Conditions, Competition, and Leaders }\end{array}$ & Karen L. Newman & Jan. 1998 \\
\hline $\begin{array}{l}\text { No. 134: To Restructure or Not to Restructure: Informal Activities and } \\
\text { Enterprise Behavior in Transition }\end{array}$ & $\begin{array}{l}\text { Clifford Gaddy and Barry W. } \\
\text { Ickes }\end{array}$ & May 1998 \\
\hline No. 133: Management 101: Behavior of Firms in Transition Economies & Josef C. Brada & Mar. 1998 \\
\hline $\begin{array}{l}\text { No. } 132 \text { Published in: Quarterly Journal of Economics, "Interfirm } \\
\text { Relationships and Informal Credit in Vietnam," 114(4), Nov. 1999, pgs. } \\
\text { 1285-1320 }\end{array}$ & $\begin{array}{l}\text { John McMillan and Christopher } \\
\text { Woodruff }\end{array}$ & Feb. 1998 \\
\hline $\begin{array}{l}\text { No. } 131 \text { Published in: Comparative Economic Studies, "Will } \\
\text { Restructuring Hungarian Companies Innovate? An Investigation Based } \\
\text { on Joseph Berliner's Analysis of Innovation in Soviet Industry." Vol. } \\
\text { 40, No. 2, Summer 1998, pp. 53-74. }\end{array}$ & John B. Bonin and Istvan Abel & Mar. 1998 \\
\hline $\begin{array}{l}\text { No. 130: Published in The American Economic Review, "Changing } \\
\text { Incentives of the Chinese Bureaucracy." May, } 1998 .\end{array}$ & David D. Li & Jan. 1998 \\
\hline $\begin{array}{l}\text { No. 129: Restructuring Investment in Transition: A Model of the } \\
\text { Enterprise Decision }\end{array}$ & Richard E. Ericson & Jan. 1998 \\
\hline $\begin{array}{l}\text { No. } 128 \text { Published in: Comparative Economic Studies, "Job Rights in } \\
\text { Russian Firms: Endangered or Extinct Institutions?" Vol. 40, No. 4, } \\
\text { Winter 1998, pp. 1-32. }\end{array}$ & Susan J. Linz & Jan. 1998 \\
\hline No. 127: Accounting for Growth in Post-Soviet Russia & $\begin{array}{l}\text { Daniel Berkowitz and David N. } \\
\text { DeJong }\end{array}$ & Jan. 1998 \\
\hline $\begin{array}{l}\text { No. } 126 \text { Published in: Economics of Transition, "From Federalism, } \\
\text { Chinese Style, to Privatization Chinese Style," } 7(1), 1999 \text {, pgs. 103-31 }\end{array}$ & $\begin{array}{l}\text { Yuanzheng Cao, Yingyi Qian, } \\
\text { and Barry R. Weingast }\end{array}$ & Dec. 1997 \\
\hline $\begin{array}{l}\text { No. 125: Market Discipline in Conglomerate Banks: Is an Internal } \\
\text { Allocation of Cost of Capital Necessary as Incentive Device? } \\
\text { Forthcoming in Financial Systems in Transition: The Design of } \\
\text { Financial Systems in Central Europe eds. Anna Meyendorff and Anjan } \\
\text { Thakor. }\end{array}$ & $\begin{array}{l}\text { Arnoud W. A. Boot and Anjolein } \\
\text { Schmeits }\end{array}$ & Nov. 1997 \\
\hline $\begin{array}{l}\text { No. 124: Financial Discipline in the Enterprise Sector in Transition } \\
\text { Countries: How Does China Compare? }\end{array}$ & $\begin{array}{l}\text { Shumei Gao and Mark E. } \\
\text { Schaffer }\end{array}$ & Feb. 1998 \\
\hline $\begin{array}{l}\text { No. 123: Considerations of an Emerging Marketplace: Managers' } \\
\text { Perceptions in the Southern African Economic Community }\end{array}$ & Brent Chrite and David Hudson & Feb. 1998 \\
\hline No. 122: A Model of the Informal Economy in Transition Economies & $\begin{array}{l}\text { Simon Commander and Andrei } \\
\text { Tolstopiatenko }\end{array}$ & Nov. 1997 \\
\hline $\begin{array}{l}\text { No. 121: Local Labour Market Dynamics in the Czech and Slovak } \\
\text { Republics }\end{array}$ & $\begin{array}{l}\text { Peter Huber and Andreas } \\
\text { Worgotter }\end{array}$ & Nov. 1997 \\
\hline $\begin{array}{l}\text { No. 119: Published in Academy of Management Review, "Organizational } \\
\text { Transformation during Institutional Upheaval," } 25 \text { (3), 2000, p. 602-619 }\end{array}$ & Karen L. Newman & Mar. 1998 \\
\hline
\end{tabular}




\begin{tabular}{|c|c|c|}
\hline No. 118: Industrial Decline and Labor Reallocation in Romania & John S. Earle & Oct. 1997 \\
\hline No. 117: Notes for an Essay on the Soft Budget Constraint & Lorand Ambrus-Lakatos & Jan. 1997 \\
\hline No. 116: Labor Demand During Transition in Hungary & Gabor Korosi & Oct. 1997 \\
\hline No. 115: Enterprise Performance and Managers' Profiles & $\begin{array}{l}\text { Simeon Djankov and Stijn } \\
\text { Claessens }\end{array}$ & Dec. 1997 \\
\hline $\begin{array}{l}\text { No. 114b Employment and Wages in Enterprises under Communism } \\
\text { and in Transition: Evidence From Central Europe and Russia }\end{array}$ & $\begin{array}{l}\text { Swati Basu, Saul Estrin, and Jan } \\
\text { Svejnar }\end{array}$ & Apr. 2000 \\
\hline $\begin{array}{l}\text { No. 114: Employment and Wage Behavior of Enterprises in Transitional } \\
\text { Economies }\end{array}$ & $\begin{array}{l}\text { Swati Basu, Saul Estrin, and Jan } \\
\text { Svejnar }\end{array}$ & Oct. 1997 \\
\hline $\begin{array}{l}\text { No. 113: Preliminary Evidence on Active Labor Programs' Impact in } \\
\text { Hungary and Poland }\end{array}$ & Christopher J. O’Leary & Oct. 1997 \\
\hline $\begin{array}{l}\text { No. 111: Unemployment Benefits and Incentives in Hungary: New } \\
\text { Evidence }\end{array}$ & Joachim Wolff & Oct. 1997 \\
\hline $\begin{array}{l}\text { No. 110: Published in: Empirical Economics, "Long-Term } \\
\text { Unemployment, Unemployment Benefits and Social Assistance: The } \\
\text { Polish Experience" Empirical-Economics; 23(1-2), 1998, pp. 55-85. }\end{array}$ & $\begin{array}{l}\text { Marek Gora and Christoph M. } \\
\text { Schmidt }\end{array}$ & Apr. 1997 \\
\hline $\begin{array}{l}\text { No. } 109 \text { Published in: Industrial and Labor Relations Review, "Markets } \\
\text { for Communist Human Capital: Returns to Education and Experience in } \\
\text { Post-Communist Czech Republic and Slovakia." 51(3), Apr. 1998, pp. } \\
\text { 401-423. }\end{array}$ & Robert S. Chase & Oct. 1997 \\
\hline $\begin{array}{l}\text { No. 107: The Worker-Firm Matching in the Transition: (Why) Are the } \\
\text { Czechs More Successful Than Others? }\end{array}$ & $\begin{array}{l}\text { Daniel Münich, Jan Svejnar, and } \\
\text { Katherine Terrell }\end{array}$ & Oct. 1997 \\
\hline $\begin{array}{l}\text { No. } 106 \text { Published in: Journal of Comparative Economics, "Job } \\
\text { Creation, Job Destruction and Growth of Newly Established, Privatized } \\
\text { and State-Owned Enterprises in Transition Economies: Survey Evidence } \\
\text { from Bulgaria, Hungary, and Romania," 26(3), Sept. 1998, pp. 429-445. }\end{array}$ & $\begin{array}{l}\text { Valentijn Bilsen and Jozef } \\
\text { Konings }\end{array}$ & Sept. 1998 \\
\hline $\begin{array}{l}\text { No. 105: Getting Behind the East-West [German] Wage Differential: } \\
\text { Theory and Evidence }\end{array}$ & $\begin{array}{l}\text { Michael Burda and Christoph } \\
\text { Schmidt }\end{array}$ & May 1997 \\
\hline No. 104: The Birth of the "Wage Curve" in Hungary, 1989-95 & Gabor Kertesi and Janos Kollo & Oct. 1997 \\
\hline $\begin{array}{l}\text { No. 103: Published in: Journal of Comparative Economics, "Grime and } \\
\text { Punishment: Job Insecurity and Wage Arrears in the Russian } \\
\text { Federation" 27, 595-617 (1999). }\end{array}$ & $\begin{array}{l}\text { Hartmut Lehmann, Jonathan } \\
\text { Wadsworth, and Alessandro } \\
\text { Acquisti }\end{array}$ & Oct. 1997 \\
\hline No. 102: Social Networks in Transition & $\begin{array}{l}\text { Lorena Barberia, Simon Johnson, } \\
\text { and Daniel Kaufmann }\end{array}$ & Oct. 1997 \\
\hline $\begin{array}{l}\text { No. 101: Depreciation and Russian Corporate Finance: A Pragmatic } \\
\text { Approach to Surviving the Transition }\end{array}$ & Susan J. Linz & Nov. 1997 \\
\hline No. 100: Romanian Financial System Reform & $\begin{array}{l}\text { Anna Meyendorff and Anjan V. } \\
\text { Thakor }\end{array}$ & Nov. 1997 \\
\hline $\begin{array}{l}\text { No. 99: Proceedings of the Conference on Strategic Alliances in } \\
\text { Transitional Economies, held May 20, } 1997 \text { at the Davidson Institute }\end{array}$ & Edited by Cynthia Koch & May 1997 \\
\hline No. 98: Institutions, Strain and the Underground Economy & Daniel Daia & Nov. 1997 \\
\hline No. 97: Structure and Strain in Explaining Inter-Enterprise Arrears & Daniel Daianu & Nov. 1997 \\
\hline $\begin{array}{l}\text { No. 96: Resource Misallocation and Strain: Explaining Shocks in Post- } \\
\text { Command Economies }\end{array}$ & Daniel Daianu & Nov. 1997 \\
\hline $\begin{array}{l}\text { No. 95: Published in: Finance-a-Uver, "Czech Money Market: Emerging } \\
\text { Links Among Interest Rates." 48(2) } 1998 \text { pp. 99-109. }\end{array}$ & $\begin{array}{l}\text { Jan Hanousek and Evzen } \\
\text { Kocenda }\end{array}$ & Nov. 1997 \\
\hline $\begin{array}{l}\text { No. 94: Pre-Reform Industry and the } \\
\text { State Monopsony in China }\end{array}$ & $\begin{array}{l}\text { Xiao-Yuan Dong and Louis } \\
\text { Putterman }\end{array}$ & Oct. 1997 \\
\hline $\begin{array}{l}\text { No. 93: China's State-Owned Enterprises } \\
\text { In the First Reform Decade: } \\
\text { An Analysis of a Declining Monopsony }\end{array}$ & $\begin{array}{l}\text { Xiao-Yuan Dong and Louis } \\
\text { Putterman }\end{array}$ & Oct. 1997 \\
\hline No. 92: Expatriate Management in the Czech Republic & Richard B. Peterson & Sept. 1997 \\
\hline No. 91: China and the Idea of Economic Reform & Thomas G. Rawski & Apr. 1997 \\
\hline $\begin{array}{l}\text { No. } 90 \text { Published in: China Economic Review, "China's State Enterpri } \\
\text { Reform: An Overseas Perspective." Vol. 8, Spring 1997, pp. 89-98. }\end{array}$ & Thomas G. Rawski & July 1997 \\
\hline
\end{tabular}




\begin{tabular}{|c|c|c|}
\hline $\begin{array}{l}\text { No. 89: The Economic Determinants of Internal Migration Flows in } \\
\text { Russia During Transition }\end{array}$ & Annette N. Brown & July 1997 \\
\hline $\begin{array}{l}\text { No. 88: Gender Wage Gaps in China's Labor Market: Size, Structure, } \\
\text { Trends }\end{array}$ & $\begin{array}{l}\text { Margaret Maurer-Fazio, Thomas } \\
\text { G. Rawski, and Wei Zhang }\end{array}$ & July 1997 \\
\hline No. 87: Privatisation in Central and Eastern Europe & Saul Estrin & June 1997 \\
\hline $\begin{array}{l}\text { No. 86: Published in : Economics of Transition, "The Effect of } \\
\text { Privatization on Wealth Distribution in Russia." v. 7, no. 2, 1999, pp. } \\
449-65\end{array}$ & Michael Alexeev & Feb. 1998 \\
\hline $\begin{array}{l}\text { No. 85: Was Privatization in Eastern Germany a Special Case? Some } \\
\text { Lessons from the Treuhand }\end{array}$ & Uwe Siegmund & Sept. 1997 \\
\hline No. 84: Start-ups and Transition & $\begin{array}{l}\text { Daniel M. Berkowitz and David J. } \\
\text { Cooper }\end{array}$ & Sept. 1997 \\
\hline $\begin{array}{l}\text { No. 83: Which Enterprises (Believe They) Have Soft Budgets after } \\
\text { Mass Privatization? Evidence from Mongolia }\end{array}$ & $\begin{array}{l}\text { James Anderson, Georges } \\
\text { Korsun, and Peter Murrell }\end{array}$ & Oct. 1997 \\
\hline $\begin{array}{l}\text { No. 82: Published in: European Economic Review, "Unemployment } \\
\text { Dynamics and the Restructuring of the Slovak Unemployment Benefit } \\
\text { System." Apr., } 1997 \text {. }\end{array}$ & $\begin{array}{l}\text { Martina Lubyova and Jan C. van } \\
\text { Ours }\end{array}$ & June 1997 \\
\hline No. 81: Determinants of Unemployment Duration in Russia & Mark C. Foley & Aug. 1997 \\
\hline No. 80: The Many Faces of Information Disclosure & $\begin{array}{l}\text { Arnoud W.A. Boot and Anjan V. } \\
\text { Thakor }\end{array}$ & Oct. 1997 \\
\hline $\begin{array}{l}\text { No. 79: Published in: Journal of Finance, "Foreign Speculators and } \\
\text { Emerging Equity Markets."v.22, iss. 2, 2000, pp. 565-613 }\end{array}$ & $\begin{array}{l}\text { Geert Bekaert and Campbell R. } \\
\text { Harvey }\end{array}$ & Aug. 1997 \\
\hline $\begin{array}{l}\text { No. 78: The Relationship Between Economic Factors and Equity } \\
\text { Markets in Central Europe }\end{array}$ & $\begin{array}{l}\text { Jan Hanousek and Randall K. } \\
\text { Filer }\end{array}$ & June 1997 \\
\hline $\begin{array}{l}\text { No. } 77 \text { Published in: Economics of Transition, "A Gini Decomposition } \\
\text { Analysis of Inequality in the Czech and Slovak Republics During the } \\
\text { Transition," Vol. 6, No.1, May 1998, pp. 23-46. }\end{array}$ & $\begin{array}{l}\text { Thesia I. Garner and Katherine } \\
\text { Terrell }\end{array}$ & May 1998 \\
\hline $\begin{array}{l}\text { No. 76: China's Emerging Market for Property Rights: Theoretical and } \\
\text { Empirical Perspectives }\end{array}$ & $\begin{array}{l}\text { Gary H. Jefferson and Thomas G. } \\
\text { Rawski }\end{array}$ & June 1997 \\
\hline $\begin{array}{l}\text { No. 75b: Test of Permanent Income Hypothesis on Czech Voucher } \\
\text { Privatization }\end{array}$ & Jan Hanousek and Zdenek Tima & Oct. 1997 \\
\hline $\begin{array}{l}\text { No. 74: Determinants of Performance of Manufacturing Firms in Seven } \\
\text { European Transition Economies }\end{array}$ & $\begin{array}{l}\text { Stijn Claessens, Simeon Djankov, } \\
\text { and Gerhard Pohl }\end{array}$ & Feb. 1997 \\
\hline $\begin{array}{l}\text { No. } 73 \text { Published in: Economics of Transition, “The Restructuring of } \\
\text { Large Firms in Slovak Republic." Vol. 6, No. 1, May 1998, pp. 67-85 }\end{array}$ & $\begin{array}{l}\text { Simeon Djankov and Gerhard } \\
\text { Pohl }\end{array}$ & May 1998 \\
\hline $\begin{array}{l}\text { No. 72: Law, Relationships, and Private Enforcement: Transactional } \\
\text { Strategies of Russian Enterprises }\end{array}$ & $\begin{array}{l}\text { Kathryn Hendley, Peter Murrell, } \\
\text { and Randi Ryterman }\end{array}$ & Nov. 1998 \\
\hline $\begin{array}{l}\text { No. 71: Giving Credit Where Credit Is Due: The Changing Role of } \\
\text { Rural Financial Institutions in China }\end{array}$ & $\begin{array}{l}\text { Albert Park, Loren Brandt, and } \\
\text { John Giles }\end{array}$ & Mar. 1997 \\
\hline $\begin{array}{l}\text { No. 70: Privatization Versus Competition: Changing Enterprise } \\
\text { Behavior in Russia }\end{array}$ & John S. Earle and Saul Estrin & $\begin{array}{l}\text { Spring } \\
1997\end{array}$ \\
\hline $\begin{array}{l}\text { No. 69: Russian Managers under Storm: Explicit Reality and Implicit } \\
\text { Leadership Theories (A Pilot Exploration) }\end{array}$ & Igor Gurkov & Oct. 1998 \\
\hline $\begin{array}{l}\text { No. 68: The Political Economy of Central-Local Relations in China: } \\
\text { Inflation and Investment Controls During the Reform Era }\end{array}$ & Yasheng Huang & $\begin{array}{l}\text { Spring } \\
1997\end{array}$ \\
\hline $\begin{array}{l}\text { No. 67: Between Two Coordination Failures: Automotive Industrial } \\
\text { Policy in China with a Comparison to Korea }\end{array}$ & Yasheng Huang & $\begin{array}{l}\text { Spring } \\
1997\end{array}$ \\
\hline $\begin{array}{l}\text { No. } 66 \text { Published in: Post-Soviet Geography and Economics, "Red } \\
\text { Executives in Russia's Transition Economy." Vol. 27, No. 10, Nov. } \\
\text { 1996, pp. 633-651. }\end{array}$ & Susan J. Linz & Jan. 1997 \\
\hline $\begin{array}{l}\text { No. } 65 \text { Published in: Industrial and Corporate Change, "On the } \\
\text { Sequencing of Privatization in Transition Economies." Vol. 7, No. 1, } \\
1998 .\end{array}$ & $\begin{array}{l}\text { Gautam Ahuja and Sumit K. } \\
\text { Majumdar }\end{array}$ & Apr. 1997 \\
\hline $\begin{array}{l}\text { No. 64: Published in: Journal of Law and Economics, "Foreign } \\
\text { Ownership and Profitability: Property Rights, Control and the } \\
\text { Performance of Firms in Indian Industry" 42(1), Apr. 1999, pp. 209-38. }\end{array}$ & $\begin{array}{l}\text { Pradeep K. Chhibber and Sumit } \\
\text { K. Majumdar }\end{array}$ & Apr. 1997 \\
\hline
\end{tabular}




\begin{tabular}{|c|c|c|}
\hline No. 63: How Taxing Is Corruption on International Investors? & Shang-Jin Wei & Feb. 1997 \\
\hline $\begin{array}{l}\text { No. 62: What Can We Learn from the Experience of Transitional } \\
\text { Economies with Labour Market Policies? }\end{array}$ & Tito Boeri & 1997 \\
\hline $\begin{array}{l}\text { No. 61: Published in: Accounting Organizations and Society, } \\
\text { "Economic Transition, Strategy and the Evolution of Management } \\
\text { Accounting Practices: The Case of India" 24(5,6), Jul/Aug 1999, pp. } \\
\text { 379-412. }\end{array}$ & $\begin{array}{l}\text { Shannon W. Anderson and } \\
\text { William N. Lanen }\end{array}$ & Apr. 1997 \\
\hline $\begin{array}{l}\text { No. 60a: Enterprise Investment During the Transition: Evidence from } \\
\text { Czech Panel Data }\end{array}$ & Lubomír Lizal and Jan Svejnar & Dec. 1997 \\
\hline $\begin{array}{l}\text { No. 59: Published in: Journal of Law, Economics, and Organization, } \\
\text { "Institutional Environment, Community Government, and Corporate } \\
\text { Governance: Understanding China's Township-Village Enterprises." } \\
\text { 14(1), Apr. 1998, pages 1-23 }\end{array}$ & Jiahua Che and Yingyi Qian & Apr. 1997 \\
\hline No. 58: From the Grabbing Hand to the Helping Hand & Jiahua Che & June 2000 \\
\hline $\begin{array}{l}\text { No. 57: Published in: Brookings Papers on Economic Activity, "The } \\
\text { Unofficial Economy in Transition." } 1: 1998 .\end{array}$ & $\begin{array}{l}\text { Simon Johnson, Daniel } \\
\text { Kaufmann, and Andrei Schleifer }\end{array}$ & June 1997 \\
\hline No. 56: Taxes and Government Incentives: Eastern Europe vs. China & Roger H. Gordon and David D. Li & Apr. 1997 \\
\hline No. 55: Corruption and Reform & Susanto Basu and David Li & June 1996 \\
\hline $\begin{array}{l}\text { No. 54: Decentralization and the Macroeconomic Consequences of } \\
\text { Commitment to State-Owned Firms }\end{array}$ & Loren Brandt and Xiaodong Zhu & June 1997 \\
\hline $\begin{array}{l}\text { No. 53: Published in: The International Journal of Industrial } \\
\text { Organization, "Competitive Shocks and Industrial Structure: The Case } \\
\text { of Polish Manufacturing." Aug., 1999. . }\end{array}$ & $\begin{array}{l}\text { Pankaj Ghemawat and Robert E. } \\
\text { Kennedy }\end{array}$ & May 1997 \\
\hline $\begin{array}{l}\text { No. 52: Published in: The Quarterly Journal of Economics, "Insecure } \\
\text { Property Rights and Government Ownership of Firms." May, } 1998 .\end{array}$ & Jiahua Che and Yingyi Qian & May 1997 \\
\hline No. 51: Incentives, Scale Economies, and Organizational Form & $\begin{array}{l}\text { Eric Maskin, Yingyi Qian, and } \\
\text { Chenggang Xu }\end{array}$ & May 1997 \\
\hline $\begin{array}{l}\text { No. 50: Published in: Post-Soviet-Affairs, "End of the Tunnel? The } \\
\text { Effects of Financial Stabilization in Russia" Apr.-June 1997, pages 105- } \\
33\end{array}$ & $\begin{array}{l}\text { Barry W. Ickes, Peter Murrell, } \\
\text { and Randi Ryterman }\end{array}$ & Mar. 1997 \\
\hline $\begin{array}{l}\text { No. 49: The Evolution of Bank Credit Quality in Transition: Theory and } \\
\text { Evidence from Romania }\end{array}$ & $\begin{array}{l}\text { Enrico C. Perotti and Octavian } \\
\text { Carare }\end{array}$ & Oct. 1996 \\
\hline $\begin{array}{l}\text { No. 48: Where Do the Leaders Trade? Information Revelation and } \\
\text { Interactions Between the Segments of Czech Capital Markets }\end{array}$ & $\begin{array}{l}\text { Jan Hanousek and Libor } \\
\text { Nemecek }\end{array}$ & May 1997 \\
\hline $\begin{array}{l}\text { No. 47: Firms' Heterogeneity in Transition: Evidence from a Polish } \\
\text { Panel Data Set }\end{array}$ & $\begin{array}{l}\text { Irena Grosfeld and Jean-François } \\
\text { Nivet }\end{array}$ & May 1997 \\
\hline No. 46: Strategic Creditor Passivity, Regulation, and Bank Bailouts & Janet Mitchell & May 1997 \\
\hline $\begin{array}{l}\text { No. 45a: Published in: Journal of Public Economics, "Tax Rights in } \\
\text { Transition Economies: A Tragedy of the Commons." } 76,2000 \text {, pp. 369- } \\
397\end{array}$ & Daniel M. Berkowitz and Wei Li & Sept. 1997 \\
\hline $\begin{array}{l}\text { No. 44a: The Information Content of Stock Markets: Why do Emerging } \\
\text { Markets have Synchronous Stock Price Movements? (forthcoming in } \\
\text { the Journal of Financial Economics). }\end{array}$ & $\begin{array}{l}\text { Randall Morck, Bernard Yeung, } \\
\text { and Wayne Yu }\end{array}$ & Feb. 1999 \\
\hline $\begin{array}{l}\text { No. 43: Agency in Project Screening and Termination Decisions: Why } \\
\text { Is Good Money Thrown After Bad? }\end{array}$ & Chong-en Bai and Yijiang Wang & May 1997 \\
\hline $\begin{array}{l}\text { No. 42: Published in: Economics of Transition, "Channels of } \\
\text { Redistribution: Inequality and Poverty in the Russian Transition." Vol. } 7 \\
\text { (2) } 1999 .\end{array}$ & $\begin{array}{l}\text { Simon Commander, Andrei } \\
\text { Tolstopiatenko, and Ruslan } \\
\text { Yemtsov }\end{array}$ & May 1997 \\
\hline $\begin{array}{l}\text { No. 41: Published in: Economics of Transition, "Labour Market } \\
\text { Characteristics and Profitability: Econometric Analysis of Hungarian } \\
\text { Exporting Firms, 1986-1995" 6(1), May 1998, pages 145-62 }\end{array}$ & László Halpern and Gabor Korosi & May 1997 \\
\hline $\begin{array}{l}\text { No. 40: Published in: the Harvard Law Review, "The Tragedy of the } \\
\text { Anticommons: Property in the Transition from Marx to Markets." Jan. } \\
\text { 1998. }\end{array}$ & Michael Heller & Feb. 1997 \\
\hline No. 39: Privatization and Managerial Efficiency & $\begin{array}{l}\text { Olivier Debande and Guido } \\
\text { Friebel }\end{array}$ & May 1997 \\
\hline
\end{tabular}




\begin{tabular}{|c|c|c|}
\hline $\begin{array}{l}\text { No. } 38 \text { Published in: The Quarterly Journal of Economics, } \\
\text { "Disorganization." Vol. 112, No. 4, Nov. 1997, pp. 1091-1126. }\end{array}$ & $\begin{array}{l}\text { Olivier Blanchard and Michael } \\
\text { Kremer }\end{array}$ & Jan. 1997 \\
\hline $\begin{array}{l}\text { No. 37: Published in: Economics of Transition, "Transition and the } \\
\text { Output Fall." 7(1), 1999, pages 1-28. }\end{array}$ & $\begin{array}{l}\text { Gérard Roland and Thierry } \\
\text { Verdier }\end{array}$ & Mar. 1997 \\
\hline $\begin{array}{l}\text { No. 36: Restructuring an Industry During Transition: A Two-Period } \\
\text { Model }\end{array}$ & Richard Ericson & Sept. 1996 \\
\hline No. 34: The East-West Joint Venture: BC Torsion Case Study & $\begin{array}{l}\text { Sonia Ferencikova and Vern } \\
\text { Terpstra }\end{array}$ & Dec. 1998 \\
\hline $\begin{array}{l}\text { No. } 33 \text { Published in: Journal of Comparative Economics, "Quantifying } \\
\text { Price Liberalization in Russia." Vol. 26, No. 4, Dec. 1998, pp. 735-737. }\end{array}$ & $\begin{array}{l}\text { Daniel Berkowitz, David DeJong, } \\
\text { and Steven Husted }\end{array}$ & Dec. 1998 \\
\hline No. 32: What Can North Korea Learn from China's Market Reforms? & John McMillan & Sept. 1996 \\
\hline $\begin{array}{l}\text { No. 31: Published in: China-Economic-Review, "Towards a Model of } \\
\text { China as a Partially Reformed Developing Economy Under a } \\
\text { Semifederalist Government." 9(1), Spring 1998, pages 1-23. }\end{array}$ & Yijiang Wang and Chun Chang & Mar. 1997 \\
\hline $\begin{array}{l}\text { No. 30: Convergence in Output in Transition Economies: Central and } \\
\text { Eastern Europe, } 1970-1995\end{array}$ & Saul Estrin and Giovanni Urga & Feb. 1997 \\
\hline $\begin{array}{l}\text { No. 29: Published in: Economics of Transition, "Altered Band and } \\
\text { Exchange Volatility." Volume 6, no. 1, 1998, 173-181. }\end{array}$ & Evzen Kocenda & Mar. 1997 \\
\hline $\begin{array}{l}\text { No. 28: Published in: Quarterly Journal of Economics, "Public Versus } \\
\text { Private Ownership of Firms: Evidence from Rural China." Volume 113, } \\
\text { no. 3, Aug. 1998, 773-808. }\end{array}$ & Hehui Jin and Yingyi Qian & Jan. 1997 \\
\hline $\begin{array}{l}\text { No. 27: East-West Joint Ventures in a Transitional Economy: The Case } \\
\text { of Slovakia }\end{array}$ & Sonia Ferencikova & Mar. 1997 \\
\hline $\begin{array}{l}\text { No. 26: Published in Economic Analysis "Behavior of a Slovenian Firm } \\
\text { in Transition" Vol. 1, no. 1, 1998, 57-73. }\end{array}$ & Janez Prasnikar & Feb. 1997 \\
\hline $\begin{array}{l}\text { No. 25: Cultural Encounters and Claims to Expertise in Postcommunist } \\
\text { Capitalism }\end{array}$ & Michael D. Kennedy & Feb. 1997 \\
\hline $\begin{array}{l}\text { No. 24: ZVU a.s.: Investment Funds on the Board of Directors of an } \\
\text { Engineering Giant }\end{array}$ & Tory Wolff & Aug. 1995 \\
\hline $\begin{array}{l}\text { No. 23: The Role of Investment Funds in the Czech Republic (joint } \\
\text { publication with Czech Management Center) }\end{array}$ & Dusan Triska & June 1996 \\
\hline $\begin{array}{l}\text { No. 22: Czech Investment Fund Industry: Development and Behaviour } \\
\text { (joint publication with Czech Management Center) }\end{array}$ & Richard Podpiera & May 1996 \\
\hline $\begin{array}{l}\text { No. 21: Restructuring of Czech Firms: An Example of Gama, a.s. (joint } \\
\text { publication with Czech Management Center) }\end{array}$ & Antonin Bulin & June 1996 \\
\hline $\begin{array}{l}\text { No. 20: YSE Funds: A Story of Czech Investment Funds (joint } \\
\text { publication with Czech Management Center) }\end{array}$ & Michal Otradovec & Nov. 1995 \\
\hline $\begin{array}{l}\text { No. 19: První Investicni a.s., The First Investment Corporation (joint } \\
\text { publication with Czech Management Center) }\end{array}$ & Jaroslav Jirasek & Aug. 1995 \\
\hline $\begin{array}{l}\text { No. 18: PPF a.s., The First Private Investment Fund (joint publication } \\
\text { with Czech Management Center) }\end{array}$ & Michal Otradovec & Nov. 1995 \\
\hline $\begin{array}{l}\text { No. } 17 \text { Published in: Post-Soviet Geography and Economics, "Russia's } \\
\text { Managers in Transition: Pilferers or Paladins?" 37(7) (Sept. 1996), pp. } \\
\text { 397-426. }\end{array}$ & Susan J. Linz and Gary Krueger & Nov. 1996 \\
\hline $\begin{array}{l}\text { No. 16: Banks in Transition-Investment Opportunities in Central } \\
\text { Europe and Russia, Edited Transcript from } 31 \text { May } 1996 \text { Conference in } \\
\text { New York City }\end{array}$ & $\begin{array}{l}\text { With commentary and edited by } \\
\text { Anna Meyendorff }\end{array}$ & Jan. 1997 \\
\hline $\begin{array}{l}\text { No. 15: Marketing in Transitional Economies: Edited Transcript \& } \\
\text { Papers from } 1 \text { Apr. } 1996 \text { Conference in Ann Arbor, Michigan }\end{array}$ & $\begin{array}{l}\text { Compiled by The Davidson } \\
\text { Institute }\end{array}$ & Dec. 1996 \\
\hline $\begin{array}{l}\text { No. 14: Pensions in the Former Soviet Bloc: Problems and Solutions. } \\
\text { Published by Council on Foreign Relations. "The Coming Global } \\
\text { Pension Crisis" New York, } 1997\end{array}$ & Jan Svejnar & Nov. 1996 \\
\hline $\begin{array}{l}\text { No. 13: Enterprise Restructuring and Performance in the Transition. } \\
\text { Forthcoming in Financial Systems in Transition: The Design of } \\
\text { Financial Systems in Central Europe eds. Anna Meyendorff and Anjan } \\
\text { Thakor. }\end{array}$ & $\begin{array}{l}\text { Lubomir Lizal, Miroslav Singer, } \\
\text { and Jan Svejnar }\end{array}$ & Dec. 1996 \\
\hline
\end{tabular}


Davidson Institute Working Papers are available at: www.wdi.bus.umich.edu

\begin{tabular}{|c|c|c|c|}
\hline \multicolumn{2}{|c|}{$\begin{array}{l}\text { No. } 12 \text { Published in: Journal of International Marketing, "Executive } \\
\text { Insights: Marketing Issues and Challenges in Transitional Economies." } \\
\text { Vol. 5, No. 4, 1997, pp. 95-114. Also published in: Marketing Issues in } \\
\text { Transitional Economies ed. Rajeev Batra. }\end{array}$} & Rajeev Batra & Apr. 1997 \\
\hline \multicolumn{2}{|c|}{$\begin{array}{l}\text { No. 11: Worker Trust and System Vulnerability in the Transition from } \\
\text { Socialism to Capitalism }\end{array}$} & Andrew Schotter & Aug. 1996 \\
\hline \multicolumn{2}{|c|}{$\begin{array}{l}\text { No. } 10 \text { Published in: Comparative Economic Studies, "Russian Firms in } \\
\text { Transition: Champions, Challengers, and Chaff." Vol. 39, No.2, } \\
\text { Summer 1997, pp. 1-36. }\end{array}$} & Susan J. Linz & July 1996 \\
\hline \multicolumn{2}{|c|}{$\begin{array}{l}\text { No. 9: Corporate Debt Crisis and Bankruptcy Law During the } \\
\text { Transition: The Case of China }\end{array}$} & David D. Li and Shan Li & Dec. 1995 \\
\hline \multicolumn{2}{|c|}{$\begin{array}{l}\text { No. } 8 \text { Published in: Journal of Comparative Economics, "A Theory of } \\
\text { Ambiguous Property Rights in Transition Economies: The Case of the } \\
\text { Chinese Non-State Sector." Vol. 23, No. 1, Aug. 1996, pp. 1-19. }\end{array}$} & David D. Li & June 1996 \\
\hline \multicolumn{2}{|c|}{$\begin{array}{l}\text { No. 7: The Foreign Economic Contract Law of China: Cases and } \\
\text { Analysis }\end{array}$} & Dong-lai Li & June 1993 \\
\hline \multicolumn{2}{|c|}{$\begin{array}{l}\text { No. 3: Bank Privatization in Hungary and the Magyar Kulkereskedelmi } \\
\text { Bank Transaction }\end{array}$} & $\begin{array}{l}\text { Kormendi and Kare } \\
\text { tterly }\end{array}$ & May 1996 \\
\hline $\begin{array}{l}\text { Replacing No. 1: Journal of Comparative Economics } \\
\text { Symposium on "Bank Privatization in Central Europe and } \\
\text { Russia." Vol. 25, No. 1, Aug. } 1997 .\end{array}$ & \multicolumn{2}{|c|}{$\begin{array}{l}\text { "Bank Privatization in Transitional } \\
\text { Economies," Roger Kormendi and Edward } \\
\text { Snyder. }\end{array}$} & Aug. 1997 \\
\hline $\begin{array}{l}\text { Replacing No. 2: Journal of Comparative Economics } \\
\text { Symposium on "Bank Privatization in Central Europe and } \\
\text { Russia." Vol. 25, No. 1, Aug. } 1997 .\end{array}$ & \multicolumn{2}{|c|}{$\begin{array}{l}\text { "Transactional Structures of Bank } \\
\text { Privatizations in Central Europe and } \\
\text { Russia," Anna Meyendorff and Edward A. } \\
\text { Snyder. }\end{array}$} & Aug. 1997 \\
\hline $\begin{array}{l}\text { Replacing No. 4: Journal of Comparative Economics } \\
\text { Symposium on "Bank Privatization in Central Europe and } \\
\text { Russia." Vol. 25, No. 1, Aug. } 1997 .\end{array}$ & \multicolumn{2}{|c|}{$\begin{array}{l}\text { "Bank Privatization in Poland: The Case of } \\
\text { Bank Slaski," Jeffery Abarbaness and John } \\
\text { Bonin. }\end{array}$} & Aug. 1997 \\
\hline $\begin{array}{l}\text { Replacing No. 5: Journal of Comparative Economics } \\
\text { Symposium on "Bank Privatization in Central Europe and } \\
\text { Russia." Vol. 25, No. 1, Aug. } 1997 .\end{array}$ & \multicolumn{2}{|c|}{$\begin{array}{l}\text { "Bank Privatization in Post-Communist } \\
\text { Russia: The Case of Zhilsotsbank," Jeffery } \\
\text { Abarbanell and Anna Meyendorff }\end{array}$} & Aug. 1997 \\
\hline $\begin{array}{l}\text { Replacing No. 6: Journal of Comparative Economics } \\
\text { Symposium on "Bank Privatization in Central Europe and } \\
\text { Russia." Vol. 25, No. 1, Aug. } 1997 .\end{array}$ & \multicolumn{2}{|c|}{$\begin{array}{l}\text { "The Czech Republic's Commercial Bank: } \\
\text { Komercni Banka," Edward A. Snyder and } \\
\text { Roger C. Kormendi. }\end{array}$} & Aug. 1997 \\
\hline
\end{tabular}

